\title{
Inventory and analysis of the distribution of Viséan corals from the Guadiato Area (Córdoba, SW Spain)
}

\author{
Sergio RODRÍGUEZ ${ }^{1,2^{*}}$, Ian D. SOMERVILLE ${ }^{3}$, Pedro CÓZAR ${ }^{2}$, Ismael CORONADO ${ }^{1}$ \\ \& Ismail SAID
}

${ }^{1}$ Departamento de Paleontología, Universidad Complutense de Madrid, c/José Antonio Novais, 12, 28040 Madrid, Spain; sergrodr@geo.ucm.es; Ismael.coronado@gmail.com

${ }^{2}$ Instituto de Geociencias (CSIC, UCM), c/José Antonio Novais, 12, 28040 Madrid, Spain; pcozar@ucm.es

${ }^{3}$ UCD School of Earth Sciences, University College Dublin, Belfield, Dublin 4, Ireland; Ian.Somerville@ucd.ie

${ }^{4}$ Division du Patrimoine Géologique (DPG), Direction du Développement Minier (DDM), Ministère de l'Énergie, des Mines, de l'Eau et de l'Environnement, Rue Abou Marouane Essadi BP: Rabat Instituts 6208 - Haut Agdal, Rabat, Morocco; ismsaid@gmx.fr

* Corresponding author

Rodríguez, S., Somerville, I.D., Cózar, P., Coronado, I. \& Said, I. 2016. Inventory and analysis of the distribution of Viséan corals from the Guadiato Area (Córdoba, SW Spain) [Inventario y análisis de la distribución de los corales del Viseense del área del Guadiato (Córdoba, SO de España)]. Spanish Journal of Palaeontology, 31 (1), 181-220.

\section{ABSTRACT}

The coral content of the Viséan rocks from the Guadiato Area (SW Spain) have been studied during the last 25 years. Part of the coral assemblages have been previously described, but never as whole. The 69 recorded coral species belonging to Rugosa, Tabulata and Heterocorallia are illustrated. The family Antiphyllidae is represented by two genera and three species; the family Laccophyllidae is represented by one species; the family Cyathaxoniidae is represented by one genus and two species; the family Amplexidae is represented by one species; the family Zaphrentoididae is represented by one species; the family Plerophyllidae is represented by one species; the family Polycoeliidae is represented by one species; the family Pentaphyllidae is represented by one species; the family Cyathopsidae is represented by four genera and five species; the family Bothrophyllidae is represented by one species, the family Aulophyllidae is represented by nine genera and ten species; the family Palaeosmiliidae is represented by four genera and four species; the family

\section{RESUMEN}

El registro de corales fósiles del Viseense del Área del Guadiato (SO de España) ha sido estudiado durante los últimos 25 años. Parte de las asociaciones de corales habían sido previamente descritas, nunca en su conjunto. Se figuran las 69 especies registradas pertenecientes a Rugosa, Tabulata y Heterocorallia. La familia Antiphyllidae está representada por dos géneros y tres especies; la familia Laccophyllidae está representada por una especie; la familia Cyathaxoniidae está representada por un género y dos especies; la familia Amplexidae está representada por una especie; la familia Zaphrentoididae está representada por una especie; la familia Plerophyllidae está representada por una especie; la familia Polycoeliidae está representada por una especie; la familia Pentaphyllidae está representada por una especie; la familia Cyathopsidae está representada por cuato generos y cinco especies; la familia Bothrophyllidae está representada por una especie; la familia Aulophyllidae está representada por nueve géneros y diez especies; la familia Palaeosmiliidae 
Lithostrotionidae is represented by five genera and sixteen species; the family Axophyllidae is represented by three genera and thirteen species; the family Geyerophyllidae is represented by one species; the family Heterophyllidae is represented by two genera and two species; the family Syringoporidae is represented by one species; the family Multithecoporidae is represented by one genus and three species; the family Syringolitidae is represented by one species; the family Pyrgiidae is represented by one species. The degree of abundance and diversity is regarded as moderate and the degree of endemism is low. The significance of the coral assemblages for biostratigraphy, palaeobiogeography and environmental palaeontology is analysed.

Keywords: Guadiato Area, Ossa-Morena, Mississippian, Carboniferous, Rugosa.

\section{INTRODUCTION}

The Guadiato Area (Córdoba Province, SW Spain) is located in a region between the Ossa-Morena and the Centroibérica zones (Chacón et al., 1974; DelgadoQuesada et al., 1977; Apalategui et al., 1985; Gabaldón et al., 1985a, b), that has been also called the LusitanMarianic Zone (San José et al., 2004). Carboniferous rocks ranging in age from Viséan to Moscovian occur in the region. The Mississippian rocks are mainly marine, whereas the Pennsylvanian rocks are continental in origin. Rugose and tabulate corals are common in the Viséan from the Guadiato Area. Some previous papers (Rodríguez \& Falces, 1996; Rodríguez et al., 2001a, b, 2002, 2004, 2007; Rodríguez, 2004; Rodríguez \& Said, 2009; Rodríguez $\&$ Somerville, 2014) involved the description of some components of the assemblages recorded in that region, but a comprehensive publication including the complete assemblage is lacking. That is the purpose of this paper, as well as a homage in honour of Robert H. ('Roberto') Wagner, who studied the Peñarroya-Belmez-Espiel coalfield, provided helpful information on the neighbouring Mississippian Guadiato Area and shared with us pleasant and valuable days in the field.

The studied region is located along the Guadiato Valley that runs from NW to SE for more than $50 \mathrm{~km}$ and bounded by ridges composed of Precambrian to Devonian rocks (Figs 1,2). Some hills also occur in the valleys, which are composed of resistant Mississippian limestones. The Mississippian rocks from the Guadiato Area have been divided into three tectonostratigraphic units (Cózar \& Rodríguez, 1999a): Fresnedoso Unit, Viséan in age, composed mainly of siliciclastic rocks, the Sierra del Castillo Unit, composed mainly of Viséan limestones, está representada por cuatro géneros y cuatro especies; la familia Lithostrotionidae está representada por cinco géneros y dieciseis especies; la familia Axophyllidae está representada por tres géneros y trece especies; la familia Geyerophyllidae está representada por una especie; la familia Heterophyllidae está representada por dos genera y two especies; la familia Syringoporidae está representada por una especie; la familia Multithecoporidae está representada por un género y tres especies; la familia Syringolitidae está representada por una especie; la familia Pyrgiidae está representada por una especie. El grado de abundancia y diversidad se considera como moderado y el grado de endemismo es bajo. Se analiza el interés de las asociaciones de corales en estudios bioestratigráficos, paleogeográficos y de palentología ambiental.

Palabras clave: Área del Guadiato, Ossa-Morena, Misisípico, Carbonífero, Rugosa. and the San Antonio-La Juliana Unit, composed of both, siliciclastic rocks and limestones, mostly Serpukhovian in age, but containing Viséan limestone olistolites. The coral assemblages that are described in the present paper belong to the Sierra del Castillo Unit and to the olistolites in the San Antonio-La Juliana Unit (Fig. 2). The studied outcrops are located along the Guadiato river valley, from the neighbourhood of the Fuenteagria spa (in the SE) to the vicinity of Fuenteobejuna (in the NW) (Fig. 2). In addition, the outcrops from El Casar and Campillo de Llerena are also included, because they represent the north-western prolongation of the Guadiato Area that is covered for 20 kilometres by Tertiary rocks (Fig. 1). El Casar yielded a rich assemblage, but outcrops near Campillo de Llerena are quite poor in corals and they are not included in the main sections studied (Fig. 1).

The detailed stratigraphy of the Viséan from the Guadiato Area has been published previously (Cózar \& Rodríguez, 1999a, b, c, d, 2000, 2001; Cózar et al., 2003; Rodríguez-Martínez et al., 2003; Rodríguez et al., 2007) and it will be not discussed in detail in this paper. More than 50 outcrops and sections have been studied, but only some of them yielded common or abundant corals and some others comprise Serpukhovian, not Viséan rocks. The location of the main Viséan sections is shown in Figures 2, 3 and the stratigraphic interval covered by them is shown in Figure 4. The time interval covered by the Sierra del Castillo Unit and the olistolites in the San Antonio-La Juliana Unit is quite short, comprising only the Asbian and lower Brigantian substages (Cózar \& Rodríguez, 1999a; Rodríguez et al., 2007; Rodríguez \& Somerville, 2007). Marine Lower Viséan or Tournaisian rocks have been not recorded in Sierra Morena, and the first marine sediments in the area are related to the Upper 


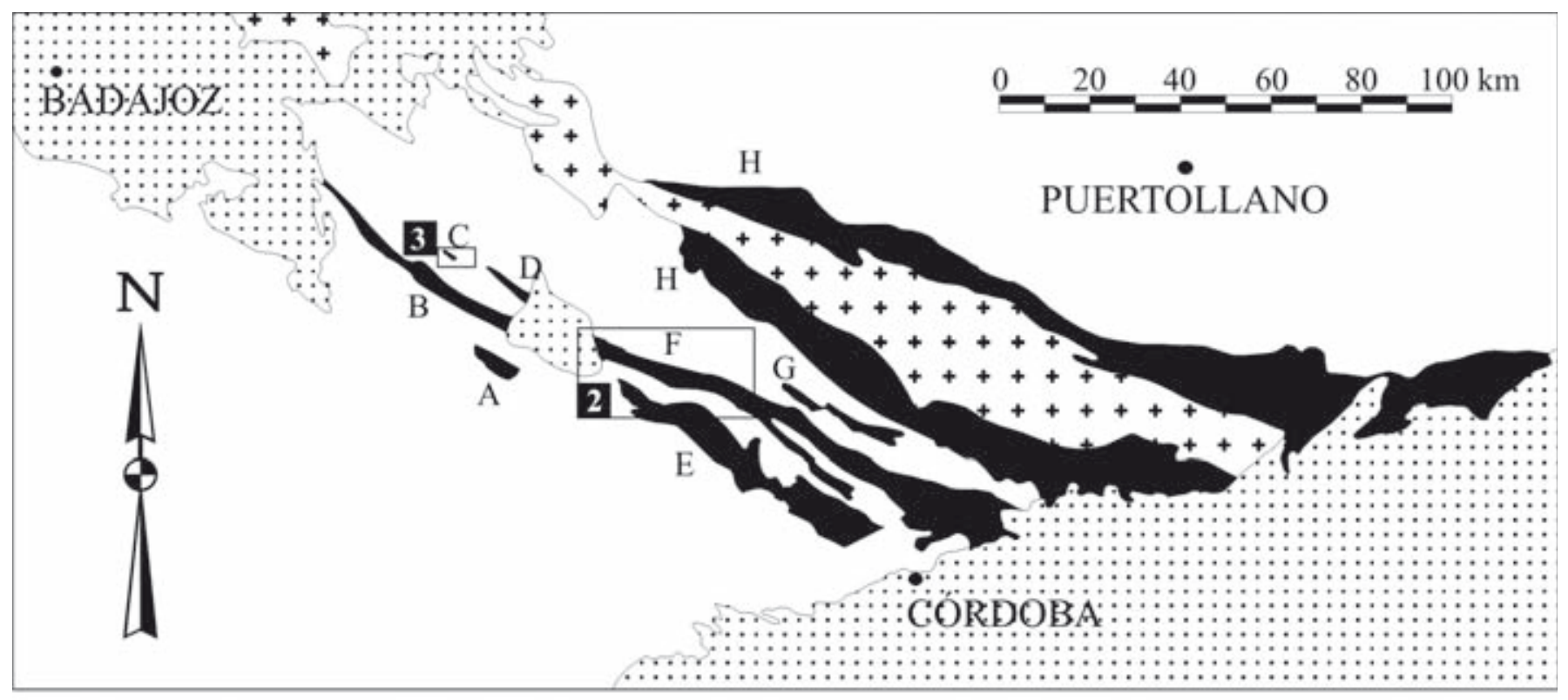

$::::::$ Post-Palaeozoic $\quad+++$ Pedroches Batholith

Pre-Carboniferous Palaeozoic

Carboniferous outcrops in the Ossa-Morena/Centroiberian boundary:

A.- Berlanga, B.- Matachel, C.- El Casar, D.- Campillo de Llerena, E.- Benajarafe,

F.- Guadiato-Guadalmellato, G.- Guadalbarbo, H.- Pedroches.

Figure 1. Location of the Guadiato Area Carboniferous outcrops in SW Spain.

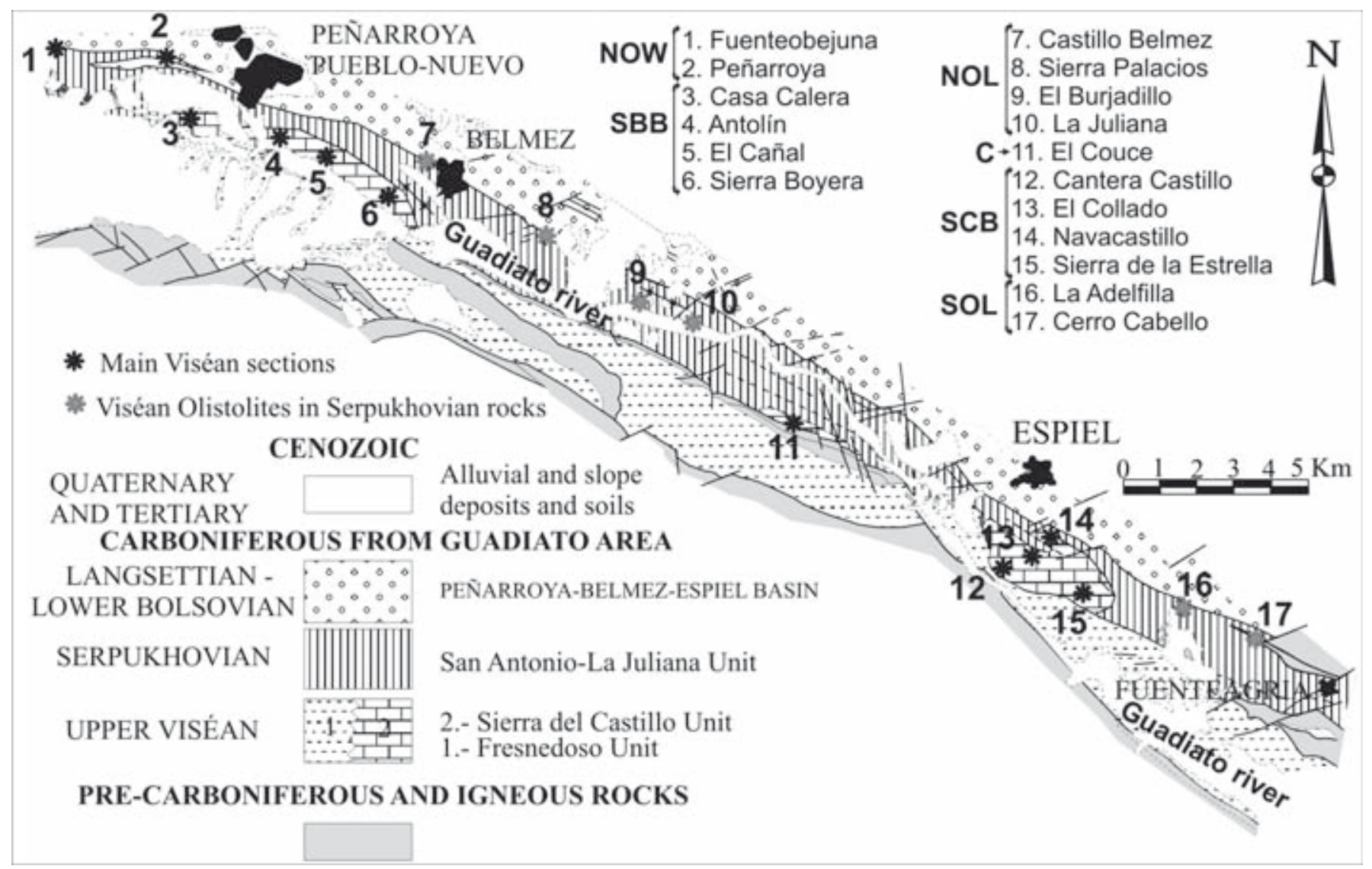

Figure 2. Location of the studied outcrops in the Guadiato Area. For location in a broader region, see Fig. 1. Modified from Cózar \& Rodríguez (1999a). 


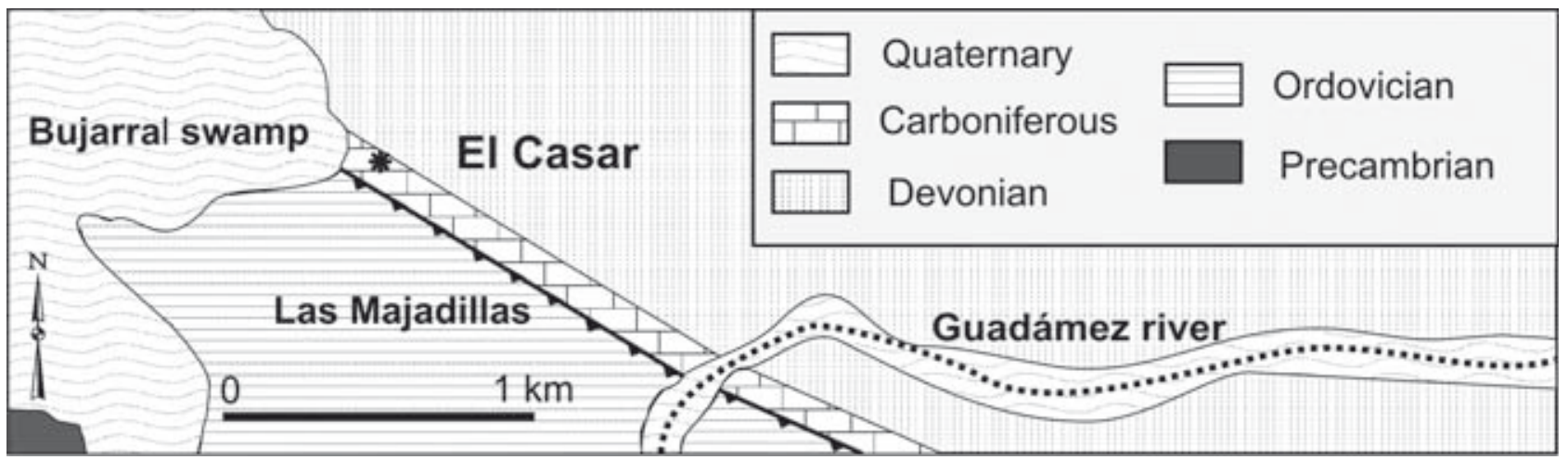

Figure 3. Location of the El Casar outcrop. For location in a broader region, see Fig. 1. Modified from Rodríguez \& Said (2009).

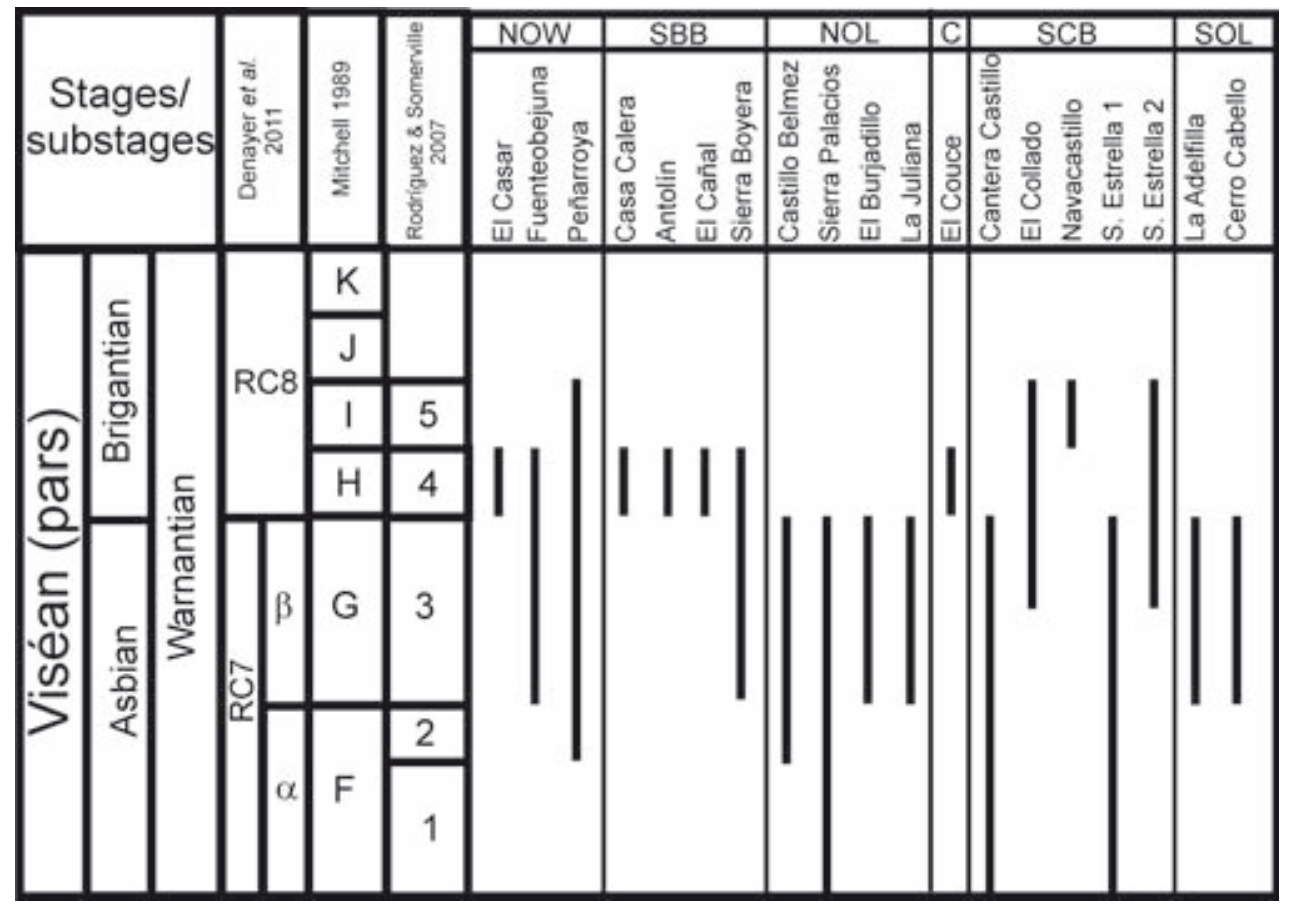

Figure 4. Stratigraphic record of the studied outcrops. NOW: Northwestern outcrops. SBB: Sierra Boyera Block. NOL: Northern Olistoliths. C: El Couce outcrop. SCB: Sierra del Castillo Block. SOL: Southern olistoliths.

Viséan transgression. Sedimentation during the Viséan took place in a syntectonic environment, and tectonic movements affected the original platforms. It implies that the carbonate platforms where the corals lived have been rarely preserved. More commonly, the corals occur in debris flows or olistolites and consequently they are not in growth position. The main exception to that is the Sierra del Castillo Block, where a large part of a shallow-water platform has been preserved. Some of the corals there are preserved in growth position, but nevertheless, reworking processes have taken place due to storms, and most coral beds show broken specimens and/or everted colonies.

As the region was tectonically active during the Variscan Orogeny, the outcrops are commonly separated by faults and thrusts. However, following the Variscan Orogeny, the area has suffered erosion, but little sedimentation during the Mesozoic and Cenozoic eras. No significant thickness of sediments accumulated over the Mississippian rocks. It implies that the microstructural preservation of corals is quite good, except where the outcrops are very close to tectonic structures or volcanic rocks.

\section{TAXONOMY}

This inventory is not a taxonomic review. The main aim of this publication is to provide an illustrated guide of the corals recorded in the Guadiato Area. So, no detailed descriptions are included here, but only the diagnosis and some remarks when necessary. The diagnoses of authors are cited in all cases. No synonymies are provided, but references to papers where they can be found are included in some of the species remarks. Transverse sections of 
all species and many longitudinal sections are provided for illustration of the Viséan coral record in the Guadiato Area, but usually only one or two figures of each species are included. Consequently, the species variability is not represented, but in the case of highly variable taxa, reference to papers where it is illustrated is specified. Some species that are still under study or without a clear specific identification are presented in open nomenclature. The geographical location and stratigraphical distribution of each species is given in Table 1 and indicated in the text.

The morphological terminology is based on that proposed by Hill $(1956,1981)$, with some additions by Poty (1981) and Rodríguez (1984). The microstructural descriptions are based on the terminology proposed by Semenoff-Tian-Chansky (1974) and some precisions by Rodríguez (1984). The taxonomic classification follows that of Hill (1981) with some variations following recently published papers.

Class ANTHOZOA Ehrenberg, 1834

Subclass RUGOSA Milne-Edwards and Haime, 1850 Order STAURIIDA Verrill, 1865

Suborder STREPTELASMATINA Wedekind, 1927

Family Antiphyllidae Iljina, 1970

Genus Rotiphyllum Hudson, 1942

Type species Densiphyllum rushianum Vaughan, 1908

Diagnosis (after Hill, 1981). Small solitary ceratoid coral. Majors straight or slightly curved towards the cardinal fossula, with dilated base. Minors absent or short and thickened. Axial ends of septa joined in an axial column or an aulos. Septa joined in four groups in juvenile stages. Cardinal fossula on the convex side of the coral, inconspicuous in mature stages. Counter and alar fossulae occasionally present. Dissepiments absent. Tabulae conical, strongly downturned towards periphery.

\section{Rotiphyllum rushianum (Vaughan, 1908)}

(Fig. 5a)

Diagnosis (after Poty, 1981). Rotiphyllum with majors joined in the centre of the corallite, forming a wide axial column, tubular in place. All elements strongly thickened.

Distribution. Recorded from El Couce and Sierra de la Estrella 1, Sierra del Castillo Unit.

Age. Asbian-Brigantian.

Rotiphyllum costatum (McCoy, 1849)

(Fig. 5b)

Diagnosis (based on the description of Hudson, 1944). Medium- to large-sized Rotiphyllum (12.5 $\mathrm{mm}$ in maximum diameter and up to 26 majors), with asymmetrical septal formula, and accelerated counter insertion in adult stages. Septa thinner towards the axis. External wall moderately thick. Minors very short or absent. Axial zone filled with stereoplasm, but may show some holes. Counter fossula may be present.

Distribution. Recorded from Sierra de la Estrella 1, Sierra del Castillo Unit.

Age. Asbian-Brigantian.

Genus Claviphyllum Hudson, 1942

Type species Claviphyllum eruca McCoy, 1849

Diagnosis (modified after Hudson, 1942). Small, conical to conical-cylindrical solitary corals with claviphylloid septal plan. Majors straight. Counter septum rhopaloid, longer and thicker than other septa, reaching the axis. The septa KL3, KL4, CL2 and CL3, rhopaloid. The septa KL1, KL2, CL1 and C not completely developed. Cardinal part in convex side. External tabulae progressively declined towards the periphery; inner tabulae domical when present, axial tabulae sometimes depressed.

\section{Claviphyllum sp.}

(Fig. 5c)

Distribution. Recorded from Sierra de la Estrella 1, Sierra del Castillo Unit.

Age. Upper Asbian-lower Brigantian.

Family Laccophyllidae Grabau, 1928

Genus Amplexocarinia Soshkina, 1941 (in Soshkina et al., 1941)

Type species Amplexocarinia muralis Soshkina, 1941 (in Soshkina et al., 1941)

Diagnosis (after Hill, 1981). Small, cylindrical solitary coral. Majors reaching the axis in juvenile stages but withdrawn in mature stages. Minors not developed. Axial ends of the septa forming a discontinuous aulos. Cardinal septum shorter in some cases. Tabulae spaced, mesashaped, resting on the tabulae next below and forming an aulos, downturned towards the periphery.

\section{Amplexocarinia sp.}

(Figs 5d-5e)

Distribution. Recorded from El Casar, Peñarroya and El Cañal.

Age. Brigantian. 
Table 1. Distribution of coral taxa in the Guadiato Area outcrops ordered by present geographical position. All are rugose species except for a few tabulates (TAB) and heterocorals (HETERO). The colours of the different outcrops indicates the structural unit in which they are located. NOW: Northwestern outcrops. SBB: Sierra Boyera Block. NOL: Northern Olistoliths. C: El Couce outcrop. SCB: Sierra del Castillo Block. SOL: Southern olistoliths.

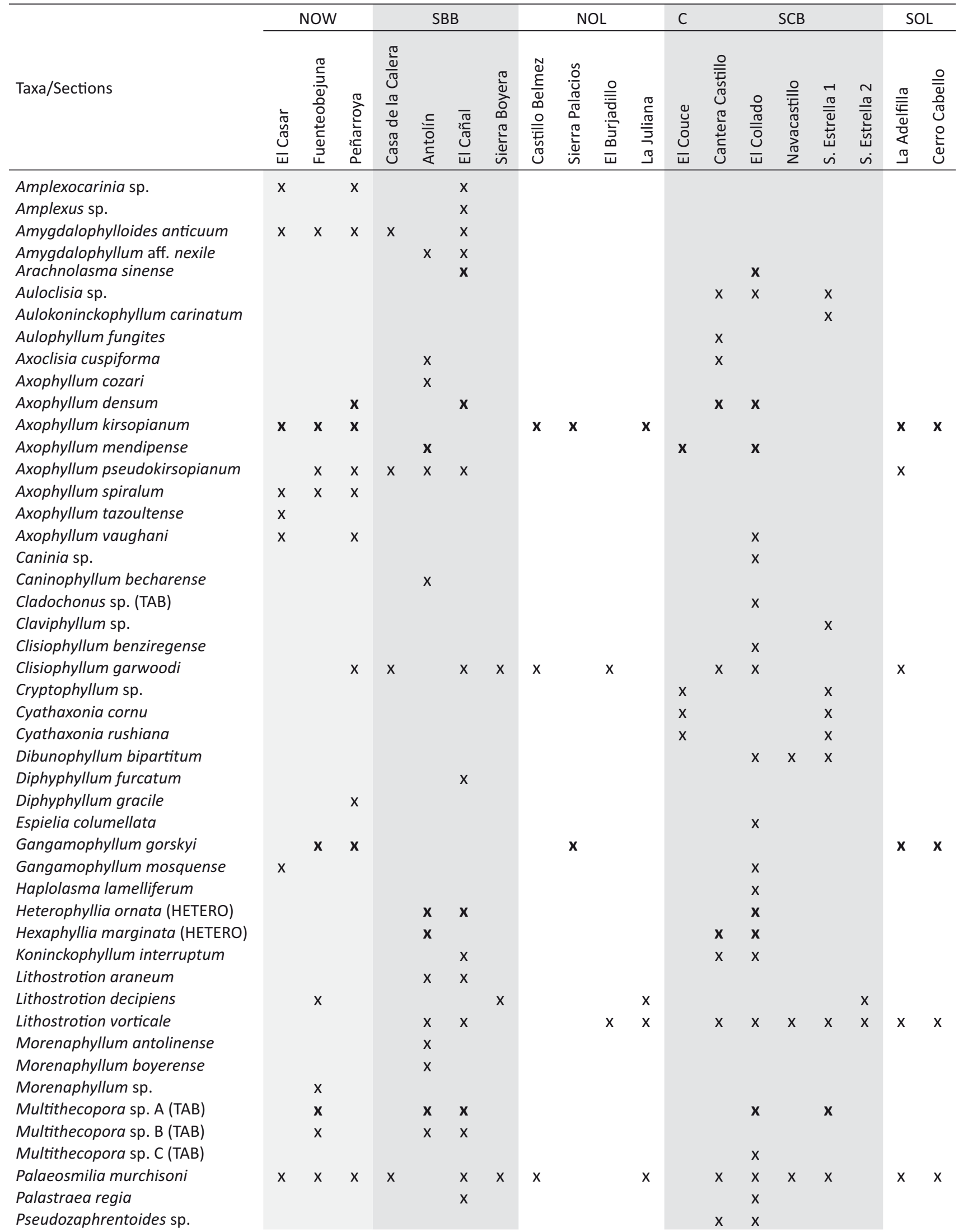




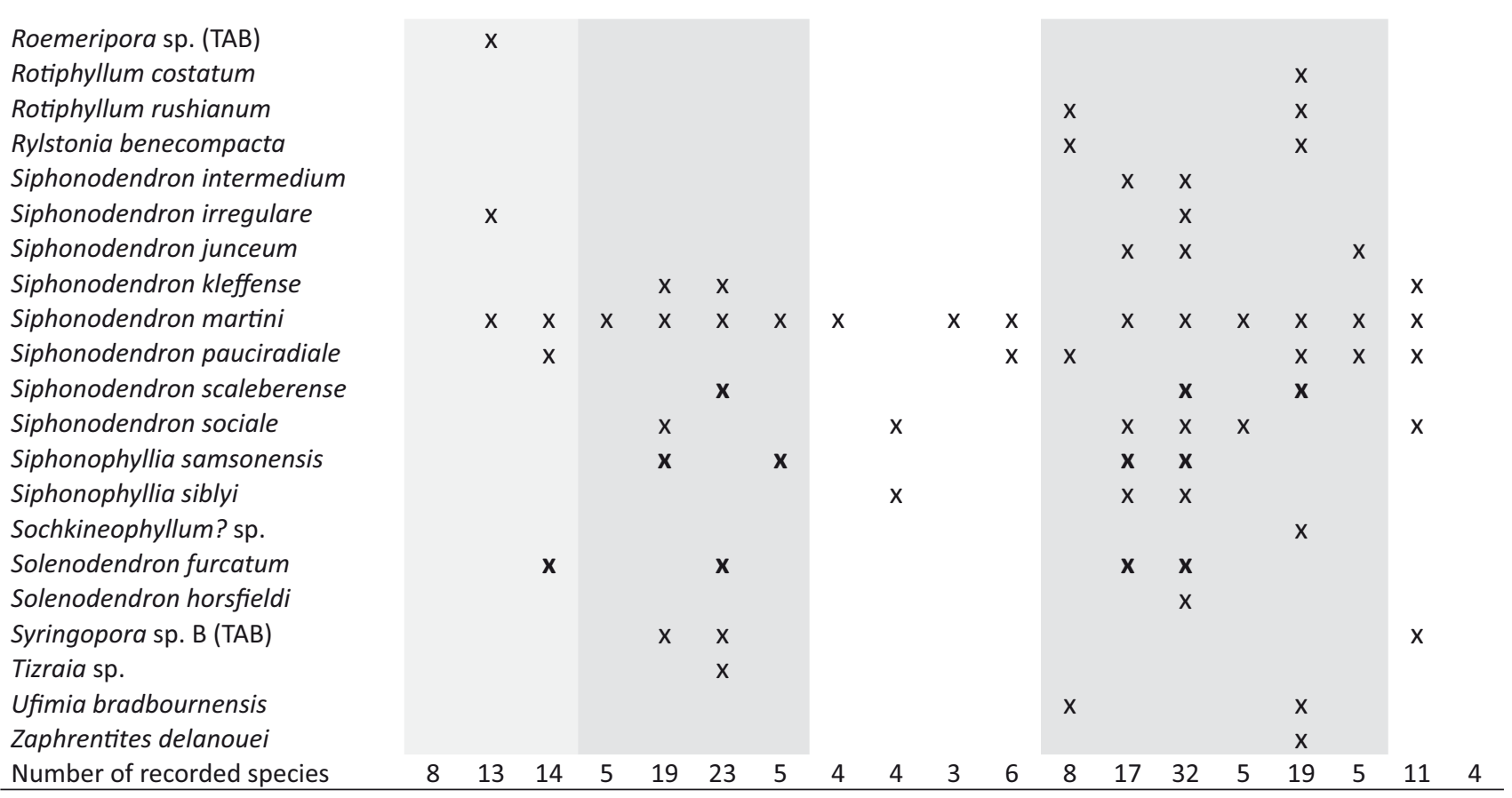
1850

Family Cyathaxoniidae Milne-Edwards \& Haime,

Genus Cyathaxonia Michelin, 1847

Type species Cyathaxonia cornu Michelin, 1847

Diagnosis (after Hill, 1981). Small, ceratoid to cylindroid solitary coral. Strong axial column developed independently of the septa but attached to them. Majors long. Minors long and contratingent. Dissepiments absent. Outer wall arched or festooned. Tabulae complete and downturned towards the periphery.

\section{Cyathaxonia cornu Michelin, 1847}

(Fig. 5f)

Diagnosis (modified from Poty, 1981). Cyathaxonia with a diameter smaller than $6 \mathrm{~mm}$. Axial column circular in transverse section. Majors may be carinate. Tabulae complete and slightly downturned towards periphery. Microstructure composed only of mesoplasm, mainly fibrous.

Distribution. Recorded from El Couce and Sierra de la Estrella, Sierra del Castillo Unit.

Age. Asbian and Brigantian.

\section{Cyathaxonia rushiana Vaughan, 1906}

(Fig. 5g)

Diagnosis (modified from Poty, 1981). Cyathaxonia reaching $8 \mathrm{~mm}$ in diameter and 44 majors. Axial column may be oval in transverse section. Microstructure mainly fibrous.

Distribution. Recorded from El Couce and Sierra de la Estrella, Sierra del Castillo Unit.

Age. Asbian and Brigantian.

Suborder STAURIINA Verrill, 1865

Family Amplexidae Chapman, 1893

Genus Amplexus Sowerby, 1814

Type species Amplexus coralloides Sowerby, 1814

Diagnosis (after Poty, 1981). Solitary coral with scolecoid to cylindrical form. Majors thin and short, amplexoid. Cardinal fossula marked by the shortened cardinal septum. Minors poorly developed. Dissepiments absent. Tabulae complete and mesa-shaped with long downturned edges.

Remarks. The genus Amplexus has been considered in a very broad sense in the literature, because amplexoid stages are reached by many different coral lineages. More than 300 references on it have been recorded, but many of them belong to different amplexoid corals. Amplexus has been regarded as polyphyletic (Fomichev, 1953), and the young stages of the types are unknown. As it needs revision, that is beyond the objectives of this paper, but we include in Amplexus a specimen that shows septa slightly longer than usual and even some dissepiments in late adult stage. 

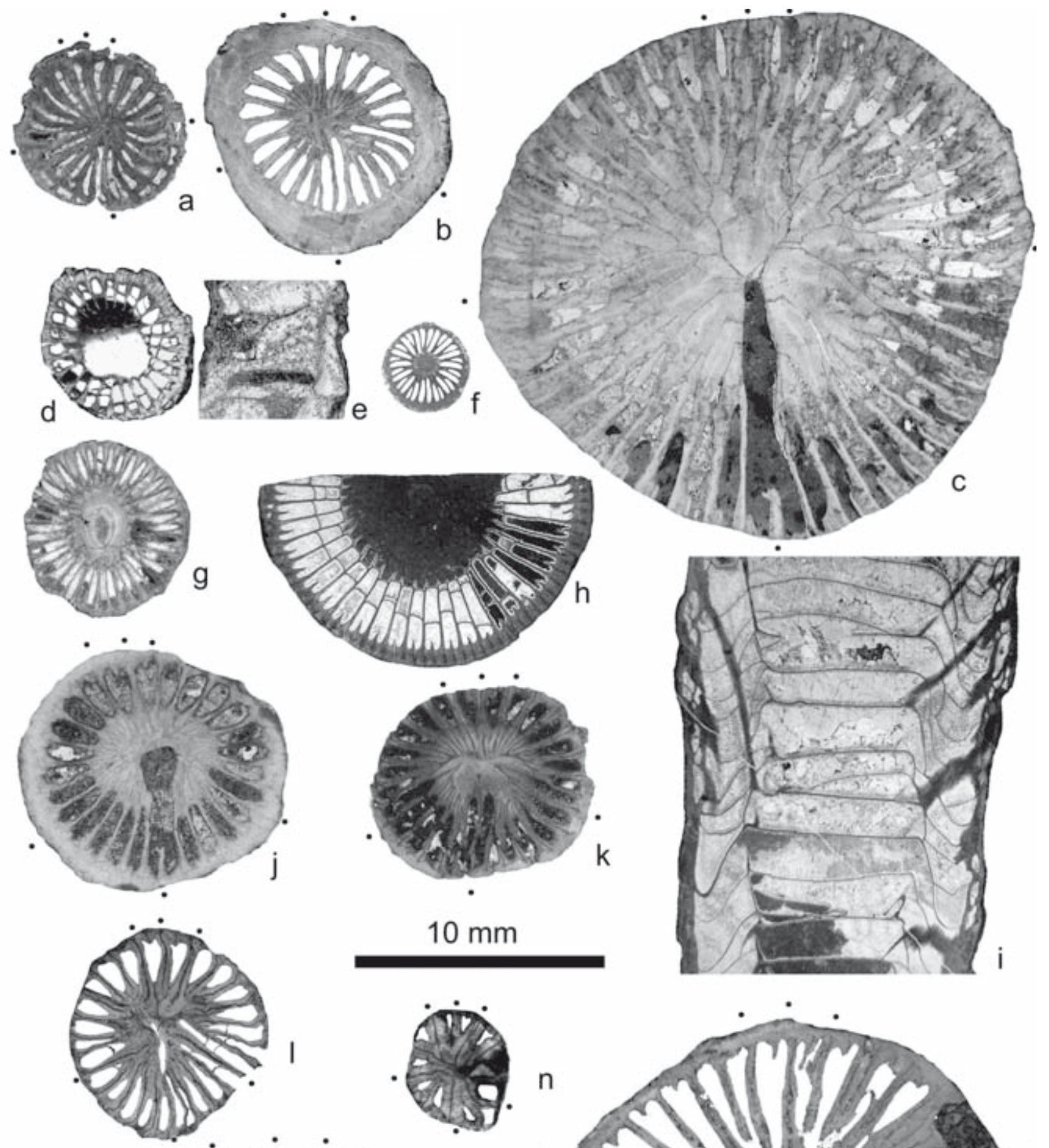

$10 \mathrm{~mm}$
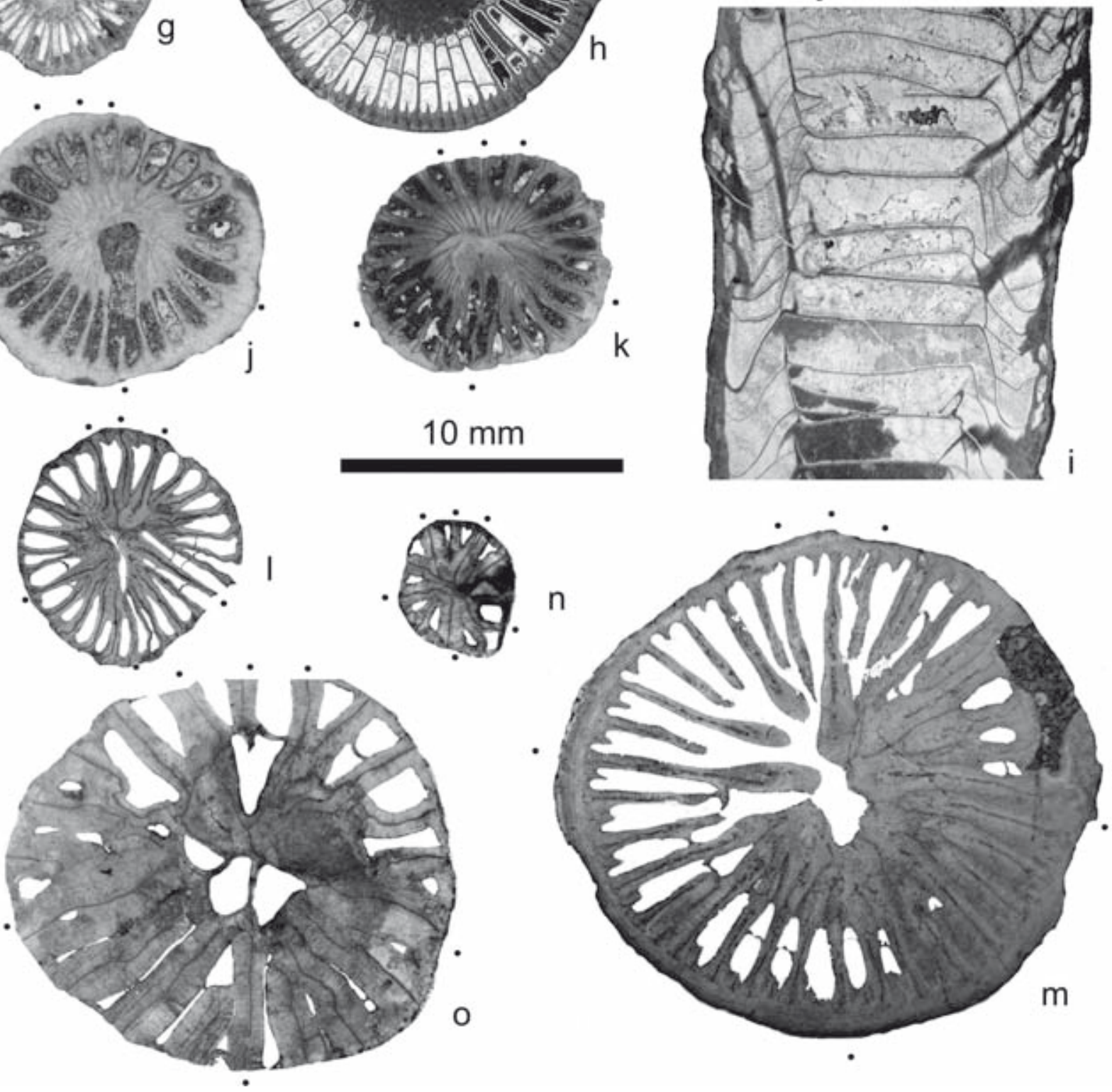
Amplexus sp.

(Figs 5h-5i)

Distribution. Recorded from El Cañal, Sierra Boyera Block, Sierra del Castillo Unit.

Age. Brigantian.

Family Zaphrentoididae Schindewolf, 1938

Subfamily Hapsiphyllinae Grabau, 1928

Genus Zaphrentites Hudson, 1941

Type species Zaphrentis parallela Carruthers, 1910

Diagnosis (modified from Hill, 1981). Slightly curved, solitary corals in which axial margins of majors commonly unite around conspicuous cardinal fossula located on concave side; cardinal septum normally elongate in early stages, shortened at maturity; counter septum normally approximately equal in length to neighbouring majors but may be slightly longer and thicker; septa pinnately arranged in cardinal quadrants, radially arranged in counter quadrants, commonly withdrawn abaxially at maturity, withdrawal normally beginning in cardinal quadrants; minors very short or absent; alar pseudofossulae commonly well developed in early stages but may be inconspicuous at maturity; tabulae complete or incomplete, commonly large domes subhorizontal or gently concave in axial area, steeply depressed at periphery and in fossula; dissepiments absent; septal microstructure showing inner, thin middle line composed of microtrabeculae, flanked by wide outer fibrous layers.

\section{Zaphrentites delanouei Milne-Edwards \& Haime, 1851} (Figs 5j-5k)

Diagnosis (after Carruthers, 1910). Zaphrentites maximum $13 \mathrm{~mm}$ in diameter and having 33 majors attached to the septa edging the cardinal fossula in the cardinal quadrants, and to the edge of the fossula in the other quadrants. Long cardinal fossula with parallel sides, occupied by a short cardinal septum. Alar fossulae welldeveloped.
Distribution. Recorded from Sierra de la Estrella 1.

Age. Upper Asbian and lowermost Brigantian.

Suborder PLEROPHYLLINA Sokolov, 1960

Family Plerophyllidae Koker, 1924

Genus Ufimia Stuckenberg, 1895

Type species Ufimia bradbournensis Wilmore, 1910

Diagnosis (based on Hill, 1981). Solitary, small; in mature stage, four septa (alars and counter-laterals) longer, thicker and more rhopaloid that others; early stages zaphrentoid; the inner rhopaloid ends are in contact at the axis in intermediate stages of development, withdrawing and becoming free in adult stages; the longer and thicker metasepta used to be located in the middle of the quadrants; the cardinal and counter septa shorten progressively; minors rudimentary or short; tabular surfaces high, domical in shape, axially depressed; without dissepiments.

\section{Ufimia bradbournensis Wilmore, 1910}

(Fig. 51)

Diagnosis (based on Hudson, 1942). Ufimia with corallum at first cornute, later cylindrical and only slightly curved. Diameter at late growth-stage constant about $12 \mathrm{~mm}$. Usual number of septa in adult stage 28. Septa straight, radial and of variable length and thickness: some septa in counter and cardinal quadrants long and markedly rhopaloid; cardinal septum shorter than other septa and about 1/3 of corallum radius; Minors contratingent but later free; counter-minors longer; marked stereocolumn, about $2 / 3$ of corallum diameter. In and immediately below calyx, septa lanceolate or lath-shaped, not in contact and do not form stereocolumn. Cardinal fossula distinguished by short cardinal septum and opposing ends of cardinallateral septa, often communicate with hollow axis of stereocolumn. Alar fossulae only distinguished from other interseptal loculi by incipient counter-lateral septa.

Figure 5. Undissepimented rugose corals. a) Rotiphyllum rushianum. Specimen SSE/14-8, transverse section, Sierra de la Estrella 1. b) Rotiphyllum costatum. Specimen SSE/18-60, transverse section, Sierra de la Estrella 1. c) Claviphyllum sp. Specimen SSE/18-118, transverse section, Sierra de la Estrella 1. d-e) Amplexocarinia sp. (d) Specimen CS/7-29, transverse section, El Casar. (e) Specimen CS/7-38, longitudinal section, El Casar. f) Cyathaxonia cornu. Specimen SSE/15-8, transverse section, Sierra de la Estrella 1. g) Cyathaxonia rushiana. Specimen SSE/14-32, Sierra de la Estrella 1. h-i) Amplexus sp. Specimen CAÑ/1-23, El Cañal, (h) transverse section; (i) longitudinal section. j-k) Zaphrentites delanouei. (j) Specimen SSE/18-81, transverse section, Sierra de la Estrella 1. (k) Specimen SSE/14-82, transverse section, Sierra de la Estrella 1. I) Ufimia bradbournensis. Specimen SSE/18-110, transverse section, Sierra de la Estrella 1. m) Sochkineophyllum? sp. Specimen SSE/18-18, transverse section, Sierra de la Estrella 1. n-o) Cryptophyllum sp. Specimen SSE/10-33, transverse sections, Sierra de la Estrella 1. (n) Young stage. (o) Adult stage. Proto-septa are indicated by black dots. Scale bar same for all pictures. 
Distribution. Recorded from El Couce and Sierra de la Estrella 1, Sierra del Castillo Unit.

Age. Upper Asbian-lower Brigantian.

Family Polycoeliidae de Fromentel, 1861

Subfamily Polycoeliinae de Fromentel, 1861

Genus Sochkineophyllum Grabau, 1928

Type species Plerophyllum artiense Soshkina, 1925

Diagnosis (modified from Moore \& Jeffords, 1941 and Cotton, 1984). Trochoid/ceratoid, moderately large; epitheca with longitudinal grooves; moderately deep calice. counter prominent reaching the centre of the section where it is thickened, but not forming column. Septa that do not reach the axis, typically 7 thickened, K, alars, 1 or 2 in each quadrant (cardinal or counter) and in all cases, the last of each series; in primitive species the thickenings are less conspicuous. Short cardinal; well marked fossula even in early stages. Tabulae well developed, more or less axially bent, usually irregular and depressed in the cardinal interseptum. No dissepiments.

\section{Sochkineophyllum? sp.}

(Fig. $5 \mathrm{~m}$ )

Distribution. Recorded in Sierra de la Estrella 1, Sierra del Castillo Unit.

Age. Upper Asbian-lower Brigantian.

Family Pentaphyllidae Schindewolf, 1942

Genus Cryptophyllum Carruthers, 1919 1919

Type species Cryptophyllum hibernicum Carruthers,

Diagnosis (after Fedorowski, 2009). Solitary, nondissepimented; cardinal protoseptum, alar and counterlateral septa strongly dominate; may meet at corallite axis or free axially; counter protoseptum permanently underdeveloped from the beginning of septogenesis; septal grooves very inconspicuous or absent.

\section{Cryptophyllum sp.}

(Figs 5n-5o)

Distribution. Recorded from El Couce and Sierra de la Estrella 1, Sierra del Castillo Unit.

Age. Upper Asbian-lower Brigantian.

Suborder CYATHOPHYLLINA Nicholson, 1889

Family Cyathopsidae Dybowski, 1873

Genus Caninia Michelin in Gervais, 1840
Type species Caninia cornucopiae Michelin in Gervais, 1840

Diagnosis (after Hill, 1981). Ceratoid to cylindrical solitary coral. Cardinal fossula on the convex side of the corallite. In juvenile stages, majors long and thickened in the cardinal quadrants. In mature stages, septa withdrawn and thin, straight or curved towards the cardinal septa. Counter septum often longer. Minors short. Dissepimentarium narrow, made of simple interseptal dissepiments and, in rare cases, first and second order lonsdaleoid dissepiments. Tabulae complete, horizontal in the axial zone, depressed in periphery.

Caninia sp.

(Fig. 6a)

Distribution. Recorded from El Collado, Sierra del Castillo Unit.

Age. Brigantian.

Genus Siphonophyllia Scouler in McCoy, 1844

Type species Siphonophyllia cylindrica Scouler in McCoy, 1844

Diagnosis (modified from Poty \& Boland 1994). Large cylindrical solitary coral. Majors numerous and long but not extending to the axis. Minors reaching the inner edge of the dissepimentarium. Septa thickened in the tabularium, particularly in the cardinal quadrants. Cardinal fossula usually well developed, with a shorter and thicker cardinal septum. Counter fossula may develop, with a shorter and thicker counter septum. Dissepimentarium wide, made of many rows of simple interseptal, V-shaped, herringbone, first and second order lonsdaleoid dissepiments. Outer wall simple and thick. Tabulae complete and horizontal in central zone, incomplete and depressed in periphery.

\section{Siphonophyllia samsonensis (Salée, 1913)}

(Fig. 6b)

Diagnosis (after Poty 1981). Large subcylindrical Siphonophyllia. Majors long, thickened in the dissepimentarium. Minors discontinuous, short or appearing as septal crests. Cardinal fossula well-developed. Dissepimentarium narrow, made of simple, V-shaped, herringbone and rare lonsdaleoid dissepiments. Tabulae horizontal in the axial zone and depressed in periphery.

Distribution. Recorded from Antolín, Sierra Boyera, Cantera Castillo, El Collado, Sierra del Castillo Unit.

Age. Upper Asbian, lower Brigantian. 

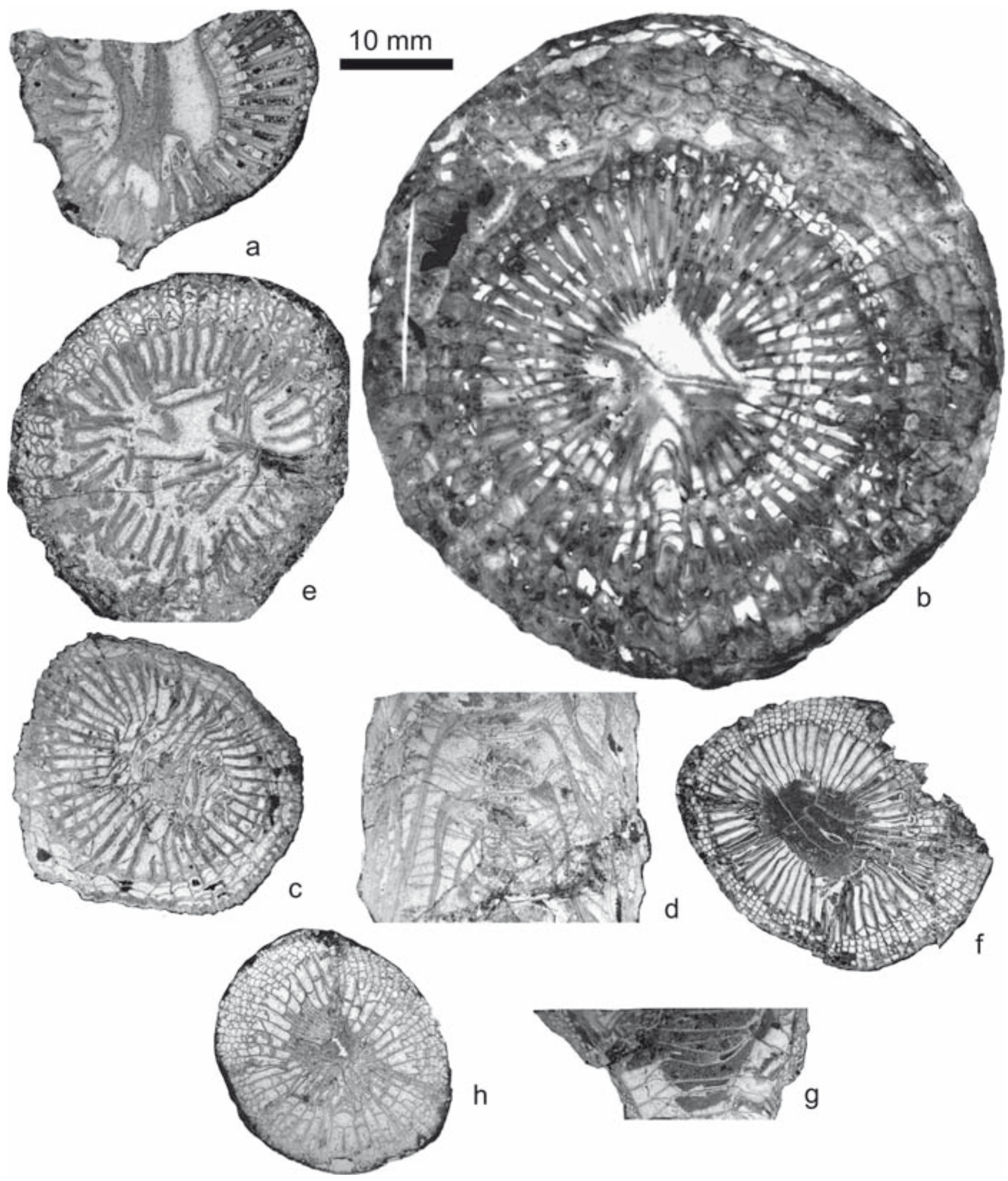

$\mathrm{h}$

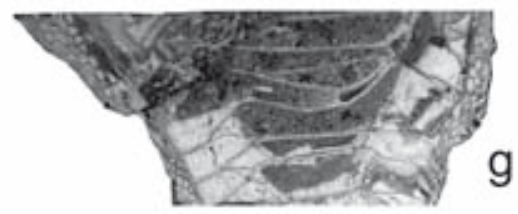

Figure 6. Cyathopsidae. a) Caninia sp. Specimen COL/7-12, El Collado, transverse section. b) Siphonophyllia samsonensis. Specimen ANT3/1-7, Antolín, transverse section. c-d) Siphonophyllia siblyi. Specimen COL/5b-11, El Collado (c) transverse section; (d) longitudinal section. e) Pseudozaphrentoides sp. Specimen CCS/10-4, Cantera Castillo, transverse section. f-g) Haplolasma lamelliferum. Specimen COL/7-10, El Collado, transverse section. h) Caninophyllum becharense. Specimen ANT/1-59, Antolín, transverse section. Scale bar same for all pictures. 
Siphonophyllia siblyi Semenoff-Tian-Chansky, 1974 (Figs 6c-6d)

Diagnosis (after Semenoff-Tian-Chansky, 1974). Siphonophyllia intermediate in size. Majors long (1/2$1 / 3$ as long as the radius), usually sinuous and thickened in the dissepimentarium. Minors poorly developed or appearing as septal crests. Cardinal fossula well-developed. Dissepimentarium wide made of simple, Vshaped, herringbone and narrow lonsdaleoid dissepiments of both orders.

Distribution. Recorded from Sierra Palacios (SanAntonio-La Juliana Unit), Cantera Castillo and El Collado (Sierra del Castillo Unit).

Age. Asbian-Brigantian.

Genus Pseudozaphrentoides Stuckenberg, 1904

Type species Pseudozaphrentoides jerofeewi Stuckenberg, 1904

Diagnosis (after Semenoff-Tian-Chansky, 1974). Conical to cylindrical solitary coral or with limited offsets. Majors thickened in the dissepimentarium. Minors short, rudimentary or absent. Cardinal fossula marked by a shorter cardinal septum. Dissepimentarium 1/3 as wide as the radius of the corallite, made of simple interseptal, V-shaped and herringbone dissepiments. Tabulae complete and horizontal.

\section{Pseudozaphrentoides sp.}

(Fig. 6e)

Distribution. Recorded from Cantera Castillo and El Collado, Sierra del Castillo Unit.

Age. Asbian-Brigantian).

Genus Haplolasma Semenoff-Tian-Chansky, 1974

Type species Caninia subibicina McCoy, 1851

Diagnosis (after Semenoff-Tian-Chansky, 1974). Solitary coral. Majors long but withdrawn from the axis with a large free zone in the central part of the tabularium. Minors short less than half the length of the majors. Small cardinal fossula with a shorter cardinal septum. Dissepimentarium of various widths, made of small simple and V-shaped dissepiments.

Haplolasma lamelliferum Semenoff-Tian-Chansky, 1974 (Figs 6f-6g)

Diagnosis (after Semenoff-Tian-Chansky, 1974). Haplolasma close to H. subibicinum in its macrostructure, but clearly different in its microstructure; it shows a thick lamellar stereoplasm.

Distribution. Recorded from El Collado, Sierra del Castillo Unit.

Age. Uppermost Asbian-Brigantian).

Family Bothrophyllidae Fomichev, 1953

Genus Caninophyllum Lewis, 1929

Type species Cyathophyllum archiaci Milne-Edwards \& Haime, 1852

Diagnosis (after Hill, 1940). Simple trochoid rugose coral with a deep open fossula and long majors typically dilated in the wide tabularium, which consists of broadly domed tabulae with down-turned edges. The minors are long and the dissepimentarium wide, consisting of fine angular dissepiments.

\section{Caninophyllum becharense Semenoff-Tian-Chansky, 1974}

(Fig. 6h)

Diagnosis (after Semenoff-Tian-Chansky, 1974). Solitary, trochoid to cylindrical coral of moderate dimensions (maximum diameter $25 \mathrm{~mm}$ ). In young and middle stages, the septa are strongly thickened in the tabularium and reach the centre, where they join in a rudimentary axial structure. In distal stages the dissepimentarium width reach half of the coral radius and the septa withdraw from axis, leaving a free zone of 5 $\mathrm{mm}$ in diameter. The minors rarely reach the dissepitheca. Presence in some stages of transeptal dissepiments of first and second order. Cardinal septum short. Axial tabulae more or less complete, horizontal or axially depressed, bent in the borders. Microstructure composed of thin mesoplasm covered by thick fibrous stereoplasm in continuity with that of the dissepitheca. Some tabulae are also covered of thick fibrous stereoplasm.

Distribution. Recorded from Antolín, Sierra Boyera Block, Sierra del Castillo Unit.

Age. Brigantian.

Family Aulophyllidae Dybowski, 1873

Subfamily Aulophyllinae Dybowski, 1873

Genus Aulophyllum Milne-Edwards \& Haime, 1850

Type species Clisiophyllum prolapsum McCoy, 1849

Diagnosis (after Poty, 1981). Sub-cylindrical solitary coral with a complex axial structure. Majors long but not connected to the axial structure, often thickened in the cardinal parts of the tabularium. Minors half as long as the 
majors. Cardinal septum slightly shorter, except in juvenile stages. Axial structure dense forming a well-defined column with a circular shape and cuspidate towards the cardinal fossula, made of densely packed radial lamellae and axial tabulae with no median plate. Cardinal fossula in the convex side of the corallite. Dissepimentarium wide, made of small simple dissepiments. Tabulae incomplete and depressed in the outer part of the tabularium. Axial tabulae densely packed, downturned towards the axis and towards the outer part of the axial column.

\section{Aulophyllum fungites (Fleming, 1828)}

(Fig. 7a)

Diagnosis. Same as for the genus.

Distribution. Recorded from Cantera Castillo, Sierra del Castillo Unit.

Age. Asbian.

Genus Auloclisia Lewis, 1927

Type species Auloclisia mutata Lewis, 1927

Diagnosis (modified from Lewis, 1927). Solitary rugose coral with an axial structure bounded by a wall that sticks out in the calice forming a conspicuous dome. It is composed of large bent tabellae crossed by radial lamellae in lower number than septa. In young stages it shows a median plate; in adult stages, it disappears. Majors are straight, thickened in the tabularium. Cardinal fossula well-marked and moderately wide. The dissepimentarium is narrow and develops late.

\section{Auloclisia sp.}

(Figs 7b-7d)

Distribution. Recorded in Cantera Castillo, El Collado and Sierra de la Estrella 1, Sierra del Castillo Unit.

Age. Asbian and lowermost Brigantian.

Subfamily Clisiophyllinae Nicholson, 1889

Genus Clisiophyllum Dana, 1846

Type species Clisiophyllum keyserlingi McCoy, 1849

Diagnosis (modified from Semenoff-Tian-Chansky, 1974; Hill, 1981; Poty, 1981). Solitary coral with numerous radially arranged, long majors reaching or closely approaching axial column, Minors generally well developed, rarely penetrating outer tabularium, cardinal septum shortened in late stages, in open cardinal fossula. Axial structure consists of median lamella and numerous radial or spirally arranged septal lamellae in axial column formed by continuous series of steeply elevated, linked axial tabellae. Tabularium weakly biform where penetrated by minors, tabulae incomplete, tabellae generally convex, less steeply elevated and fewer than those in axial column. Dissepimentarium regular, with small, concentric and, less commonly, herringbone dissepiments. Septa composed mainly of fibrous mesoplasm. Fibrous stereoplasm may sporadically occur.

Clisiophyllum benziregense Semenoff-Tian-Chansky, 1974 (Fig. 7e)

Diagnosis (modified from Semenoff-Tian-Chansky, 1974). Trochoid to ceratoid, slightly bent corals. The septa are strongly thickened in the tabularium. The axial structure is dense, with a thick median plate and about 20 radial lamellae irregularly thickened, denser in the periphery. In longitudinal section, an axial series of dense tabulae (20-30 in $10 \mathrm{~mm}$ ), steeply declined to the periphery and a periaxial series of tabulae less declined and less dense $(12-18$ in $10 \mathrm{~mm})$. The septal microstructure is composed of mesoplasm in the inner part and mesoplasm and stereoplasm in the dissepimentarium.

Distribution. Recorded from El Collado, Sierra del Castillo Unit.

\section{Age. Uppermost Asbian-lowermost Brigantian. Clisiophyllum garwoodi (Salée, 1913) (Figs $7 \mathrm{f}-7 \mathrm{~g}$ )}

Diagnosis (after Poty, 1981). Small Clisiophyllum, $9.7 \mathrm{~mm}$ in average diameter (maximum $14.3 \mathrm{~mm}$ ), and having 31 (maximum 41) majors. Minors shorter than the dissepimentarium width, very short in some cases. Axial structure 1/3-1/4 as wide as the diameter of the corallite, dense, symmetrical or poorly developed with few radial lamellae. Wide dissepimentarium.

Distribution. Recorded from Peñarroya, Casa de la Calera, El Cañal, Sierra Boyera, Castillo Belmez, El Burjadillo, Cantera Castillo, El Collado, La Adelfilla (San Antonio- La Juliana and Sierra del Castillo Units).

Age. Asbian-Brigantian.

Genus Axoclisia Semenoff-Tian-Chansky, 1974

Type species Axoclisia cuspiforma Semenoff-TianChansky, 1974

Diagnosis (after Semenoff-Tian-Chansky, 1974). Clisiophylloid solitary coral. Majors usually thickened in the tabularium. Minors long and present as septal crests in the dissepimentarium. Axial structure made of a thick axial plate, some radial lamellae and axial tabulae. Axial plate 

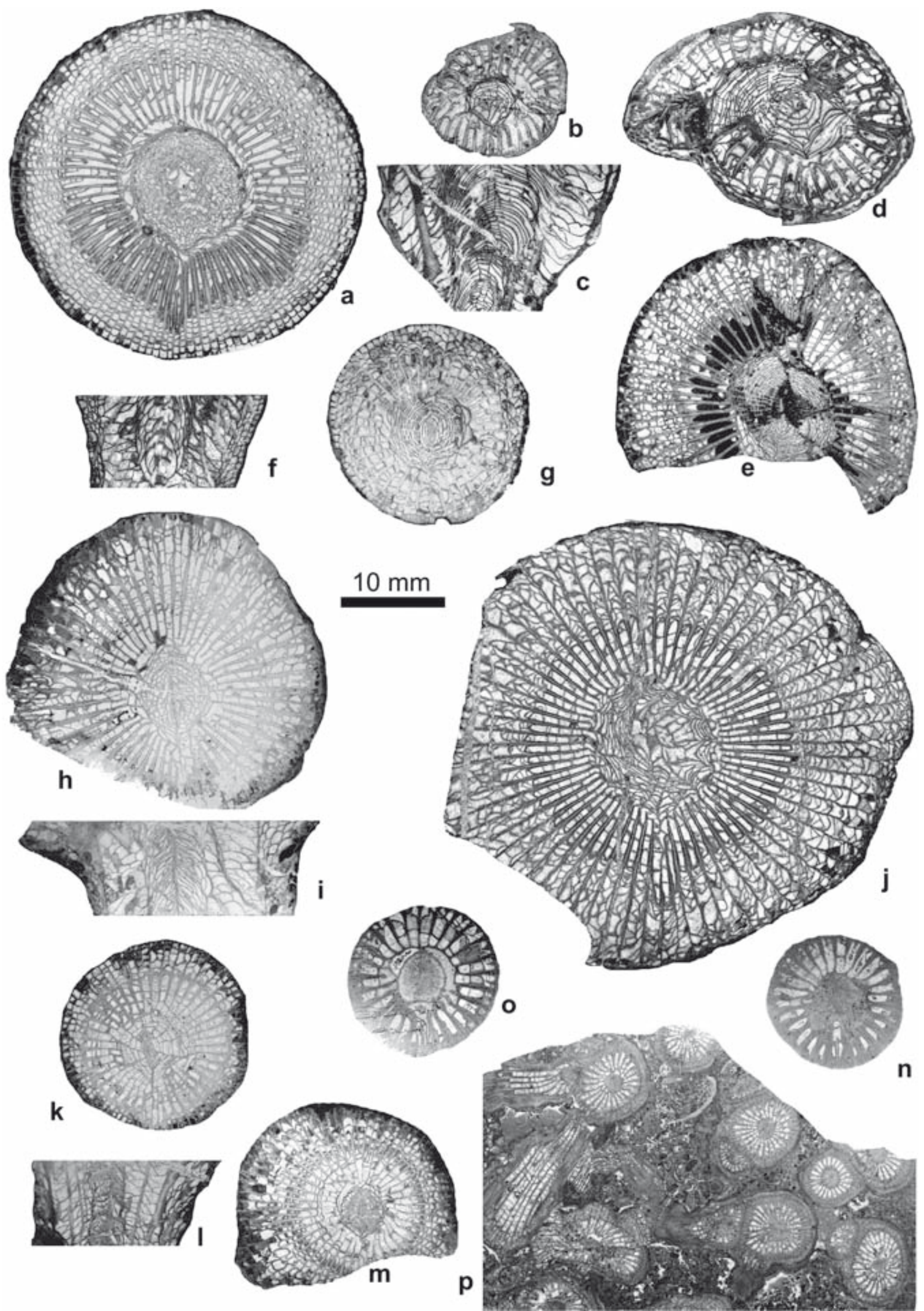
connected to the cardinal and, in some cases, to the counter septum. Radial lamellae occasionally connected to the axial ends of the majors. Dissepimentarium made of large simple and second order lonsdaleoid dissepiments. Axial tabulae upturned towards the axial plate. Periaxial tabulae domal and downturned towards the dissepimentarium.

\section{Axoclisia cuspiforma Semenoff-Tian-Chansky, 1974} (Figs 7h-7i)

Diagnosis (modified from Semenoff-Tian-Chansky, 1974). Solitary coral with clisiophylloid axial structure, with diameter reaching $1 / 3$ of the total diameter. Majors long, almost reaching the axial structure. Minors thin, cut by transeptal dissepiments of second order. Regular, rarely cross inner dissepiments. Thick median plate, joined to the cardinal septum, which is located in a well marked fossula. Many radial lamellae intersected by tabellae. Long and steeply declined dissepiments. Convex axial tabellae declined to the periphery. Granulo-fibrous septa at the periphery, fibrous in the tabularium. Lamellar stereoplasm in the dissepimentarium.

Distribution. Recorded from Antolín and Cantera Castillo, Sierra del Castillo Unit.

Age. Asbian-Brigantian.

Subfamily Dibunophyllinae Wang, 1950

Genus Dibunophyllum Thomson \& Nicholson, 1876

Type species Dibunophyllum bipartitum Thomson \& Nicholson, 1876

Diagnosis (after Hill, 1940). Large, simple rugose coral, whose variable axial structure is typically $1 / 3$ as wide as the corallum, and consists of a long median plate, a few (usually four to eight) septal lamellae on either side, and numerous tabellae, sloping steeply down at its periphery; less typically the lamellae may become curved, the median plate disappears, and the bilaterally radiate arrangement lost. Minors are short; the width of the dissepimentarium is about $2 / 3$ the length of the majors, which is $2 / 3$ the radius of the corallite; the dissepiments are frequently inosculating. Tabulae are incomplete and bracket-shaped; the tabellae are of two series, the plates of the outer series being fewer and less steeply declined than those of the inner series. The septa are not curved about the small fossula.

\section{Dibunophyllum bipartitum (McCoy, 1849)}

(Fig. 7j)

Diagnosis (after Semenoff-Tian-Chansky, 1974). Solitary, large coral with a variable axial structure that reach $1 / 3$ of the diameter. It is composed of a median lamella, a small number of radial lamellae and tabulae inclined to the periphery. The lamellae are usually anastomosed or winding. The dissepimentarium is wide, with short minors and angulate to inosculate, occasionally regular dissepiments. In rare cases the minors are long, reaching the inner border of the dissepimentarium. The septa are commonly thick in the tabularium, mainly in the cardinal quadrants. The tabulae are incomplete, tentshaped and divided in two series: axial and periaxial. The wall is lamellar with fibrous intercalations. The septa show a thin, irregular mesoplasm. The stereoplasm only occurs in the outer parts of the septa, and on some dissepiments or tabulae.

Distribution. Recorded from El Collado, Navacastillo and Sierra de la Estrella 1, Sierra del Castillo Unit.

Age. Brigantian.

Genus Arachnolasma Grabau, 1922 1920

Type species Lophophyllum sinense Yabe \& Hayasaka,

Diagnosis (after Semenoff-Tian-Chansky, 1974). Solitary coral with well-developed dissepimentarium. Axial structure having a small diameter (about $1 / 5$ of the alar diameter), composed of a thick median lamella and a low number of radial lamellae. The axial tabulae are more-orless well differentiated from the rest of the tabularium and strongly declined from the median lamella to the periphery. Septa with two phases of secretion, with the stereoplasm fibrous or lamellar in different species.

Figure 7. Aulophyllidae. a) Aulophyllum fungites. Specimen CCS/9-4, Cantera Castillo, transverse section. b-d) Auloclisia sp. Specimen CCS/9-9, Cantera Castillo, (b) transverse section, young stage; (c) longitudinal section; (d) compressed transverse section, adult stage. e) Clisiophyllum benziregense. Specimen COL/6-1, El Collado, broken transverse section. f-g) Clisiophyllum garwoodi. Specimen SSE/9-1, Sierra de la Estrella 1. (f) longitudinal section; (g) transverse section. h-i) Axoclisia cuspiforma. Specimen CCS/9-1, Cantera Castillo, (h) transverse section; (i) longitudinal section. j) Dibunophyllum bipartitum. Specimen SSE/10-102, Sierra de la Estrella 1, transverse section. k) Arachnolasma sinense. Specimen COL/1319, El Collado, transverse section. l-m) Amygdalophyllum aff. nexile. Specimen ANT/2-1-35, Antolín, (l) longitudinal section; (m) transverse section. n-o) Rylstonia benecompacta. Specimen SSE/10-10, Sierra de la Estrella 1, (n) transverse section, early adult stage; (o) Advanced adult stage. p) Espielia columellata. Specimen COL/-8-1, El Collado, transverse section. Scale bar same for all pictures. 
Arachnolasma sinense (Yabe \& Hayasaka, 1920)

(Fig. 7k)

Diagnosis (after Fedorowski, 1971). Arachnolasma with up to $28 \mathrm{~mm}$ in diameter and 47 to 61 septa of each order; dibunophylloid axial structure, occupying 1/5 of the corallite diameter and conspicuous also in longitudinal section. Minors short.

Distribution. Recorded from El Cañal and El Collado, Sierra del Castillo Unit.

Age. Brigantian.

Subfamily Amygdalophyllinae Grabau in Chi, 1935

Genus Amygdalophyllum Dun \& Benson, 1920

Type species Amygdalophyllum etheridgei Dun \& Benson, 1920

Diagnosis (after Semenoff-Tian-Chansky, 1974). Solitary coral with an axial structure. Majors usually long and connected to the axial structure, commonly thickened and carinate. Minors half as long and thinner than the majors, carinate or contratingent in some cases. Cardinal septum slightly shorter. Cardinal fossula variably developed. Axial structure made of a strong thickened axial plate, many radial lamellae, connected to the axial ends of the majors, and upturned tabulae. In some cases, axial structure reduced to some radial lamellae and tabulae. Dissepimentarium usually wide, made of simple interseptal and V-shaped dissepiments. In rare cases, some lonsdaleoid dissepiments of both orders are present. Inner row of dissepiments usually thickened. Outer wall simple and thin.

\section{Amygdalophyllum aff. nexile Vassiljuk, 1964}

(Figs 71-7m)

Distribution. El Cañal and Antolín, Sierra Boyera Block, Sierra del Castillo Unit.

Age. Brigantian.

Genus Rylstonia Hudson \& Platt, 1927

Type species Rylstonia benecompacta Hudson \& Platt, 1927

Diagnosis (after Hill 1981). Ceratoid or cylindrical solitary coral. Majors thickened in the whole corallite in juvenile stages. Majors thickened in the cardinal quadrants of the tabularium in mature stage. Minors short or not developed. Axial structure made of an axial plate connected to (nearly) all majors, several radial Iamellae and tabulae. Cardinal fossula well marked, with a short and thin cardinal septum. Dissepimentarium narrow, made of regular dissepiments and rare herringbone and lonsdaleoid dissepiments. Outer wall simple or festooned. Tabulae almost complete, downturn towards the periphery.

\section{Rylstonia benecompacta Hudson \& Platt, 1927}

(Figs 7n-7o)

Diagnosis (after Hudson \& Platt, 1927). Rylstonia maximun $17 \mathrm{~mm}$ in diameter and having 28 majors. Axial structure connected to the cardinal and counter septa. Radial lamellae mostly connected to the axial ends of the majors. Tabulae depressed in periphery, forming a gutter.

Distribution. Recorded from El Couce and Sierra de la Estrella 1, Sierra del Castillo Unit.

Age. Upper Asbian-Brigantian.

Genus Espielia Rodríguez \& Hernando, 2005

Type species Espielia columellata Rodríguez \& Hernando, 2005

Diagnosis (after Rodríguez \& Hernando, 2005). Fasciculate corals with thick wall, one to three rows of regular dissepiments, long and straight septa that reach the massive columella. Columella is thick (1/3 to $1 / 5$ of corallite diameter) with inner structure composed of medial plate and numerous radial lamellae. Tabulae are globose, gently inclined from the columella towards the periphery. Increase is peripheral. Microstructure is mainly fibrous; wall, septa and columella are composed of fascicles of fibres; dissepiments and tabulae are granular showing sporadic lamellar thickenings.

\section{Espielia columellata Rodríguez \& Hernando, 2005} (Fig. 7p)

Diagnosis. As for the genus and the mean alar diameter varies from 6 to $7 \mathrm{~mm}$, the mean tabularium diameter varies from 4.5 to $5.5 \mathrm{~mm}$ and the mean number of septa varies from 23.5 to 25.5 .

Distribution. Recorded from El Collado.

Age. Lowermost Brigantian.

Family Palaeosmiliidae Hill, 1940

Genus Palaeosmilia Milne-Edwards \& Haime, 1848

Type species Palaeosmilia murchisoni Milne-Edwards \& Haime, 1848

Diagnosis (after Rodríguez et al., 2013). Solitary corals with numerous septa radially disposed; long minors; some majors reach the axis. The cardinal fossula is narrow and reaches the axis. Incomplete tabulae disposed in two series. 
An axial series composed of globose tabellae, with the axial zone slightly depressed, and a periaxial series composed of convex tabellae that may be declined towards the dissepimentarium. Numerous, small, regular dissepiments that may be replaced in the periphery by transeptal and/ or naotic dissepiments. The microstructure is composed of a lamellar wall and fibrous septa. The peripheral part of the septa (dissepimentarium) is trabecular, but the inner zone of the septa (tabularium) is composed of fibres with water-jet disposition.

\section{Palaeosmilia murchisoni Milne-Edwards \& Haime, 1848} (Fig. 8a)

Diagnosis (after Semenoff-Tian-Chansky, 1974). Solitary, turbinate to cylindrical, more or less curved Palaeosmilia that may reach large size $(10 \mathrm{~cm}$ in diameter). A large number of septa reach the axis. Narrow fossula that reaches the axis, where it widens. Long minors that reach $1 / 2$ to $2 / 3$ of the radius of the coral. Axial tabulae incomplete forming a central dome with a depressed axial zone. Lamellar wall and totally fibrous septa without discontinuity between the mesoplasm and stereoplasm. The septa may be trabecular, at least in part. Stereoplasmatic thickenings occur on thick dissepiments.

Distribution. Recorded in all outcrops from the Guadiato Area except from Antolín, Sierra Palacios, Burjadillo and El Couce.

\section{Age. Asbian and Brigantian.}

Genus Palastraea McCoy, 1851

Type species Astraea carbonaria McCoy, 1849

Diagnosis (after Hill, 1981). Cerioid, astreoid, or aphroid Palaeosmilia.

\section{Palastraea regia (Phillips, 1836)}

(Fig. 8b)

Diagnosis. Colonial coral with numerous septa radially disposed; long minors; some majors may reach the axis. The cardinal fossula is narrow and reaches the axis. Incomplete tabulae disposed in two series. An axial series composed of globose tabellae, with the axial zone slightly depressed, and a periaxial series composed of convex tabellae that may be declined to the dissepimentarium. Numerous, small, regular dissepiments that may be replaced in the periphery by transeptal and/ or naotic dissepiments. The peripheral part of the septa (dissepimentarium) is trabecular, but the inner zone of the septa (tabularium) is composed of fibres with waterjet disposition.
Distribution. Recorded from El Cañal and El Collado.

Age. Brigantian.

Genus Aulokoninckophyllum Sando, 1976

Type species Campophyllum carinatum Carruthers, 1909

Diagnosis (modified from Sando, 1976). Solitary or pseudo-fasciculate aulate coral in which aulos is poorly defined and formed mainly by union of the axial ends of majors and partly by tahulae. Majors long, carinate; carinae of zig-zag type. Cardinal fossula ordinarily present. Dissepimentarium regular. Tabulae in aulos ordinarily flat, horizontal; tabulae in tabularium complete or incomplete, sloping down towards periphery of corallite. Increase seemingly lateral or peripheral. Septal microstructure trabecular.

\section{Aulokoninckophyllum carinatum (Carruthers, 1909)} (Fig. 8c)

Diagnosis (modified from Sando, 1976). Solitary (conical to cylindrical) or pseudo-fasciculate Aulokoninckophyllum with mature corallites $10-28 \mathrm{~mm}$ in diameter, 24-54 ordinarily strongly carinate majors and an equal number of long minors ( $1 / 2$ to $2 / 3$ length of majors), a poorly formed aulos $3-5 \mathrm{~mm}$ in diameter, tabulae numbering about $6-16$ in $5 \mathrm{~mm}$ in the aulos and about 7-10 in $5 \mathrm{~mm}$ in the tabularium, and a dissepimerntarium 2-10 $\mathrm{mm}$ wide composed of 4-16 rows of regular dissepiments. Cardinal fossula weakly to strongly developed. Increase seemingly lateral or peripheral. Septal microstructure trabecular in the dissepimentarium, water-jet fibrous in the tabularium.

Distribution. Recorded from Sierra de la Estrella 1.

Age. Upper Asbian.

Genus Koninckophyllum Thomson \& Nicholson, 1876

Type species Koninckophyllum magnificum Thomson \& Nicholson, 1876

Diagnosis (after Hill, 1939). Large solitary coral with numerous septa. Majors long but withdrawn from the axis, often thickened in the outer part of the tabularium, particularly in the cardinal quadrants. Minors long, often discontinuous in the dissepimentarium. In juvenile stages, clisiophylloid axial structure connected to the counter septum. In mature stages, axial structure reduced to a simple columella supported by conical tabulae, absent in some cases. Cardinal fossula indenting the dissepimentarium. 

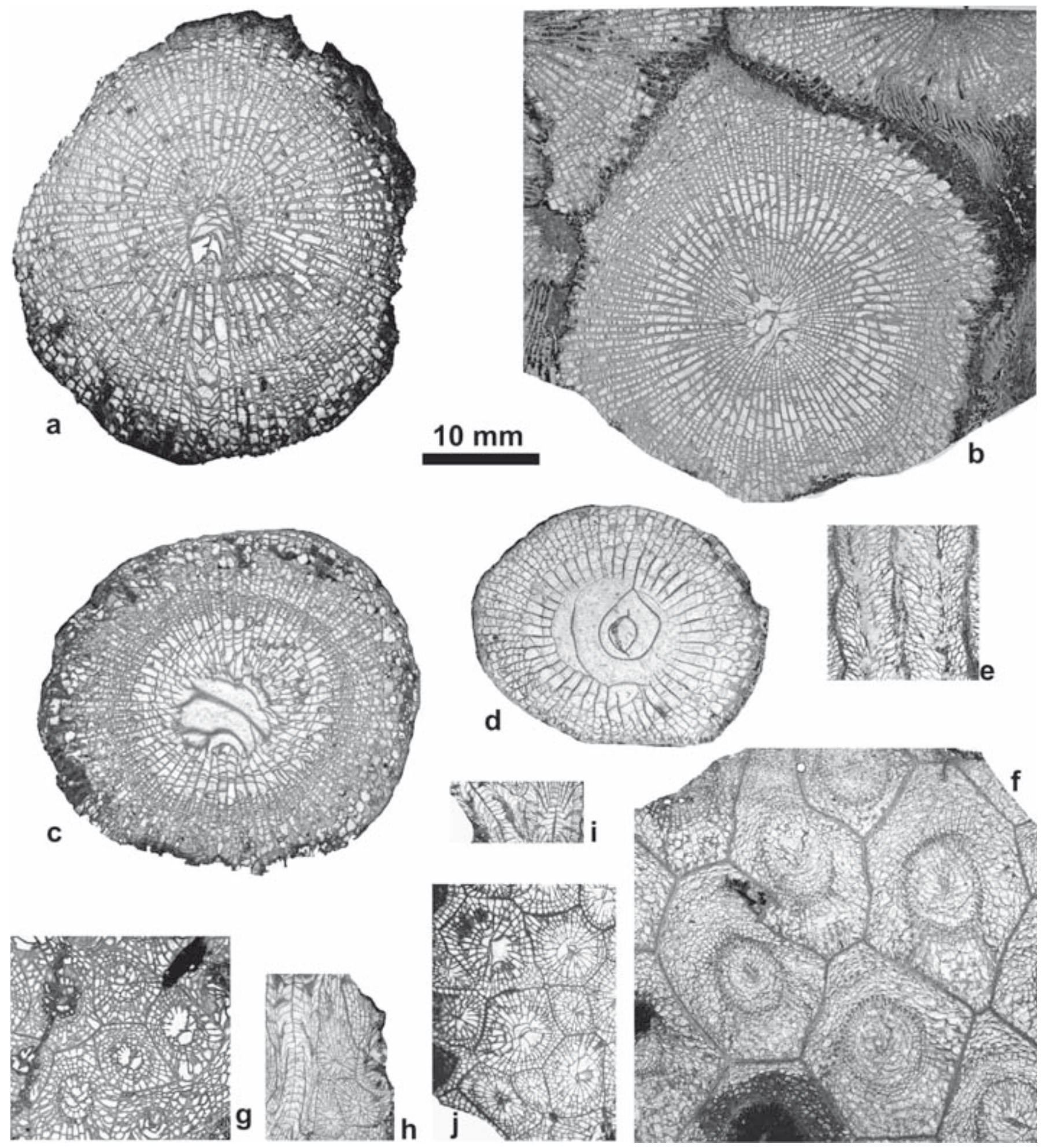

Figure 8. Palaeosmiliidae and massive lithostrotionidae. a) Palaeosmilia murchsoni. Specimen SSE/18-2, transverse section, Sierra de la Estrella 1. b) Palastraea regia. Specimen COL/9-1, El Collado, transverse section. c) Aulokoninckophyllum carinatum. Specimen SSE/10-105, transverse section, Sierra de la Estrella 1. d) Koninckophyllum interruptum. Specimen COL/146, El Collado, transverse section. e-f) Lithostrotion araneum. Specimen ANT1/1-25, Antolín, (e) longitudinal section; (f) transverse section. g-h) Lithostrotion decipiens. Specimen SSE2/21-6, Sierra de la Estrella 2, (g) transverse section; (h) longitudinal section. i-j) Lithostrotion vorticale. Specimen SSE2/22-1, Sierra de la Estrella 2, (i) longitudinal section; (j) transverse section. Scale bar same for all pictures. 
Koninckophyllum interruptum Thomson \& Nicholson, 1876

(Fig. 8d)

Diagnosis (after Semenoff-Tian-Chansky, 1974). Solitary Koninckophyllum with axial structure more rudimentary than $K$. magnificum. Possible presence of lonsdaleoid disspiments. Fibrous septa composed of thick mesoplasm with undulated borders and stereoplasm only in the tabularium.

Distribution. Recorded from El Cañal, Cantera Castillo and El Collado, Sierra del Castillo Unit.

Age. Asbian-Brigantian.

Family Lithostrotionidae D'Orbigny, 1852

Genus Lithostrotion Fleming, 1828

Type species Lithostrotion striatum Fleming, 1828 [Lithostrotion vorticale (Parkinson, 1808)]

Diagnosis (after Poty, 1981). Cerioid colonial coral. Majors long, extending to the axis and commonly connected to the columella. Minors extending to the inner edge of the dissepimentarium or slightly entering the tabularium. Columella lath-like, connected to the counter septum. Dissepimentarium of various widths, made of simple interseptal dissepiments and occasional lonsdaleoid dissepiments. Tabulae incomplete. Axial tabulae conical and peripheral tabulae horizontal or declined towards the dissepimentarium. Increase lateral and non-parricidal.

\section{Lithostrotion araneum (McCoy, 1844)}

(Figs 8e-8f)

Diagnosis (after Poty, 1981). Large Lithostrotion, maximum $5.3 \mathrm{~mm}$ in tabularium diameter and having 30 majors. Minors usually short. Dissepimentarium wide, made of numerous rows of simple interseptal, V-shaped, herringbone dissepiments and occasional lonsdaleoid dissepiments.

Distribution. Recorded from Antolín and El Cañal.

Age. Brigantian.

Lithostrotion decipiens (McCoy, 1849)

(Figs 8g-8h)

Diagnosis (after Poty, 1981). Medium-sized Lithostrotion, maximum $3 \mathrm{~mm}$ in tabularium diameter and a having maximum of 18 majors.

Distribution. Recorded from Fuenteobejuna, La Juliana, Sierra Boyera and Sierra de la Estrella 2.
Age. Brigantian.

Lithostrotion vorticale (Parkinson, 1808)

(Figs 8i-8j)

Diagnosis (after Poty, 1981). Medium-sized Lithostrotion, maximum $4.1 \mathrm{~mm}$ in tabularium diameter and having a maximum of 24 majors.

Distribution. Recorded from Antolín, El Cañal, El Burjadillo, La Juliana, Cantera Castillo, El Collado, Navacastillo, Sierra de la Estrella 1 and 2, La Adelfilla and Cerro Cabello.

Age. Upper Asbian and Brigantian.

Genus Siphonodendron McCoy, 1849 1844)

Type species Siphonodendron pauciradiale (McCoy,

Diagnosis (modified from Poty, 1981). Fasciculate coral, with corallites having styliform columella. Majors variable in length, that may reach the columella or not. Minors more-or-less developed, reduced to the dissepimentarium or penetrating slightly in the outer tabularium. Dissepimentarium well developed, composed of regular dissepiments, absent in the very small species. Complete or somewhat divided, conical tabulae. They form a channel close to the dissepimentarium. Lateral, non-parricidal increase.

\section{Siphonodendron intermedium Poty, 1981}

(Figs 9a-9b)

Diagnosis (after Poty, 1981). Phaceloid colonies. Corallites mean diameter 5.2 to $6.2 \mathrm{~mm}$ for 21-24 majors (maximum 26). Minors, half of the major in length. Usually two rows of dissepiments.

Distribution. Recorded from Cantera Castillo and El Collado.

Age. Upper Asbian and lower Brigantian.

Siphonodendron irregulare (Phillips, 1836)

(Fig. 9c)

Diagnosis (modified from Poty, 1981). Phaceloid corals with long majors usually reaching the columella, less commonly withdrawn abaxially; minors short, locally penetrating outermost tabularium; columella strongly developed, rarely discontinuous; biform morphology locally well expressed in tabularium, tabulae complete or incomplete, gently to steeply elevated adaxially, subhorizontal or concave where majors shortened, small 
peripheral plates commonly developed; dissepiments small, strongly convex to globose, usually in one or two rows, rarely up to four rows over short intervals; 20-26 (commonly 21-24) majors at corallite diameter 4-6 mm.

Distribution. Recorded in Fuenteobejuna (lower Brigantian) and El Collado.

Age. Uppermost Asbian.

Siphonodendron junceum (Fleming, 1828) (Figs 9d-9e)

Diagnosis (after Poty, 1981). Dendroid to phaceloid colonies. Small corallites, $2.3-3 \mathrm{~mm}$ in diameter and having 14-18 majors (maximum 20). Dissepiments absent.

Distribution. Recorded from Cantera Castillo, El Collado and Sierra de la Estrella 2.

Age. Uppermost Asbian, Brigantian.

\section{Siphonodendron kleffense (Schindewolf, 1927)}

(Figs 9f-9g)

Diagnosis (after Denayer et al., 2011). Dendroid or sub-cerioid colonies. Large corallites 7-9.5 $\mathrm{mm}$ in diameter (4-8 $\mathrm{mm}$ for the tabularium diameter) having 28-32 majors. Septa long, sinuous in the dissepimentarium, straight in the tabularium, usually connected to the columella. Up to four rows of simple dissepiments. Inner row of dissepiments thickened. Tabulae incomplete. Axial tabulae upturned towards the axis, other tabulae flat or slightly depressed towards the dissepimentarium.

Distribution. Recorded from Antolín, El Cañal and La Adelfilla.

Age. Brigantian.

Siphonodendron martini (Milne-Edwards \& Haime, 1851) (Figs 9h-9i)

Diagnosis (modified from Semenoff-Tian-Chansky \& Nudds, 1979; Poty, 1981). Phaceloid corals with long majors commonly reaching columella; minors short, locally penetrating outermost tabularium; columella strongly developed, rarely discontinuous; biform morphology locally well expressed in tabularium, tabulae complete or incomplete, gently to steeply elevated adaxially, small peripheral plates commonly developed; dissepiments small, strongly convex to globose, usually in twofour rows; $23-28$ (commonly 23-25) majors at corallite diameter 6-9 $\mathrm{mm}$.
Distribution. Recorded from all outcrops in the Guadiato Area, except El Casar, Sierra Palacios, El Couce and Cerro Cabello.

Age. Asbian and Brigantian.

Siphonodendron pauciradiale (McCoy, 1844)

(Fig. 9j)

Diagnosis (after Poty, 1981). Dendroid to phaceloid colonies. Corallites mean diameter $4 \mathrm{~mm}$ for 18-20 majors (maximum 22). One-two rows of dissepiments, rarely up to four.

Distribution. Recorded from Peñarroya, La Juliana, El Couce, Sierra de la Estrella 1 and 2 and La Adelfilla.

Age. Asbian and Brigantian.

Siphonodendron scaleberense Nudds \& Somerville, 1987 (Figs 9k-9m)

Diagnosis (after Nudds \& Somerville, 1987). Large corallites $13-20 \mathrm{~mm}$ in diameter (10-14 $\mathrm{mm}$ for the tabularium diameter) and having 30-41 majors and at least two rows of dissepiments.

Distribution. Recorded from El Cañal, El Collado and Sierra de la Estrella 1.

Age. Brigantian.

Siphonodendron sociale (Phillips, 1836)

(Fig. 9n)

Diagnosis (after Poty, 1981). Dendroid Siphonodendron with large corallites, 9-11 mm in diameter for 28-31 majors (maximum 34). Minors extending to the dissepimentarium width or shorter. Tabulae conical and incomplete.

Distribution. Recorded from Antolín, Sierra Palacios, Cantera Castillo, El Collado, Navacastillo and La Adelfilla.

Age. Uppermost Asbian, Brigantian.

Subfamily Diphyphyllinae Dybowski, 1873

Genus Diphyphyllum Lonsdale, 1845

Type species Diphyphyllum concinnum Lonsdale, 1845

Diagnosis (after Poty, 1981). Fasciculate coral with corallites lacking a columella and peripheral, parricidal increase. Short majors. Minors restricted to the dissepimentarium or crossing slightly its inner border. Simple regular dissepiments. Tabulae usually divided; axial tabulae flat, horizontal and having curved borders joining 
the subjacent tabulae; periaxial tabulae flat, horizontal or somewhat declined to the dissepimentarium. Small cardinal fossula present.

\section{Diphyphyllum furcatum Hill, 1940}

(Fig. 9q)

Diagnosis (after Poty, 1981). Corallites 6.2-6.9 mm in diameter and having 23-25 majors (maximum 31), twofour rows of dissepiments.

Distribution. Recorded at El Cañal, Sierra Boyera Block, Sierra del Castillo Unit.

Age. Brigantian.

$$
\text { Diphyphyllum gracile (McCoy, 1851) }
$$

(Figs 9o-9p)

Diagnosis (modified from Nudds, 1980). Diphyphyllum species with number of majors lower than 20 and one single row of dissepiments.

Distribution. Recorded at Peñarroya, olistolite block, San Antonio-La Juliana Unit.

Age. Brigantian.

Genus Solenodendron Sando, 1976

Type species Aulina horsfieldi Smith \& Yü, 1943

Diagnosis (modified from Sando, 1976). Fasciculate aulate corals in which the aulos is formed by union of deflected axial ends of majors. Major and minors carinate, carinae of zigzag type. Dissepimentarium regular. Tabulae in aulos ordinarily flat, horizontal; tabulae in tabularium slope downward towards periphery of corallite. Increase lateral in some species, axial (parricidal) in others. Trabecular septa in the dissepimentarium but water-jet fibrous in the tabularium.

\section{Solenodendron furcatum (Smith, 1925)}

(Fig. 9r)

Diagnosis (modified from Sando, 1976). Subphaceloid Solenodendron with mature corallites 3-6 $\mathrm{mm}$ in diameter, 18-22 weakly to strongly carinate majors, an aulos about $1 / 2$ the width of the tabularium (1-2 $\mathrm{mm}$ ), tabulae numbering about $10-12$ in $5 \mathrm{~mm}$ in the aulos and about $12-15$ in the tabularium, and a dissepimentarium $0.5-1 \mathrm{~mm}$ wide composed of one or two rows of regular dissepiments. Increase is parricidal, typically quadripartite. Water-jet septal microstructure.
Distribution. Recorded from Peñarroya (olistolite), El Cañal, Cantera Castillo and El Collado sections.

Age. Upper Asbian and Brigantian.

Solenodendron horsfieldi (Smith \& Yü, 1943)

(Fig. 9s)

Diagnosis (modified from Sando, 1976). Subphaceloid Solenodendron with mature corallites $8-14 \mathrm{~mm}$ in diameter, 30-32 weakly to strongly carinate majors, an aulos about $1 / 2$ the width of the tabularium $(1.5-3 \mathrm{~mm})$, tabulae numbering about 15 in $5 \mathrm{~mm}$ in the aulos and about 20 in $5 \mathrm{~mm}$ in the tabularium, and a dissepimentarium 1.5$2.5 \mathrm{~mm}$ wide composed of three or more rows of regular dissepiments. Increase is lateral, nonparricidaI. Water-jet septal microstructure.

Distribution. Recorded from El Collado section, Sierra del Castillo Unit.

Age. Lower Brigantian.

Genus Tizraia Said \& Rodríguez, 2007

Type species Tizraia berkhlii Said \& Rodríguez, 2007

Diagnosis (after Said \& Rodríguez, 2007). Fasciculate lithostrotionid corals lacking axial structure and having transeptal (lonsdaleoid) dissepiments of first and second order. Dissepitheca usually well developed and tabulae mesa-shaped, tabellae commonly form axial and peripheral series. Parricidal increase.

\section{Tizraia sp.}

(Fig. 9t)

Distribution. Recorded from El Cañal, Sierra Boyera Block, Sierra del Castillo Unit.

Age. Brigantian.

Suborder LONSDALEIINA Spassky, 1974

Family Axophyllidae Milne-Edwards \& Haime, 1851 1851

Subfamily Axophyllinae Milne-Edwards \& Haime,

Remarks. For details on the corals belonging to this subfamily synonymies, variability, descriptions, etc., see Rodríguez \& Somerville (2014).

Genus Axophyllum Milne-Edwards \& Haime, 1850

Type species Axophyllum expansum Milne-Edwards $\&$ Haime, 1850 

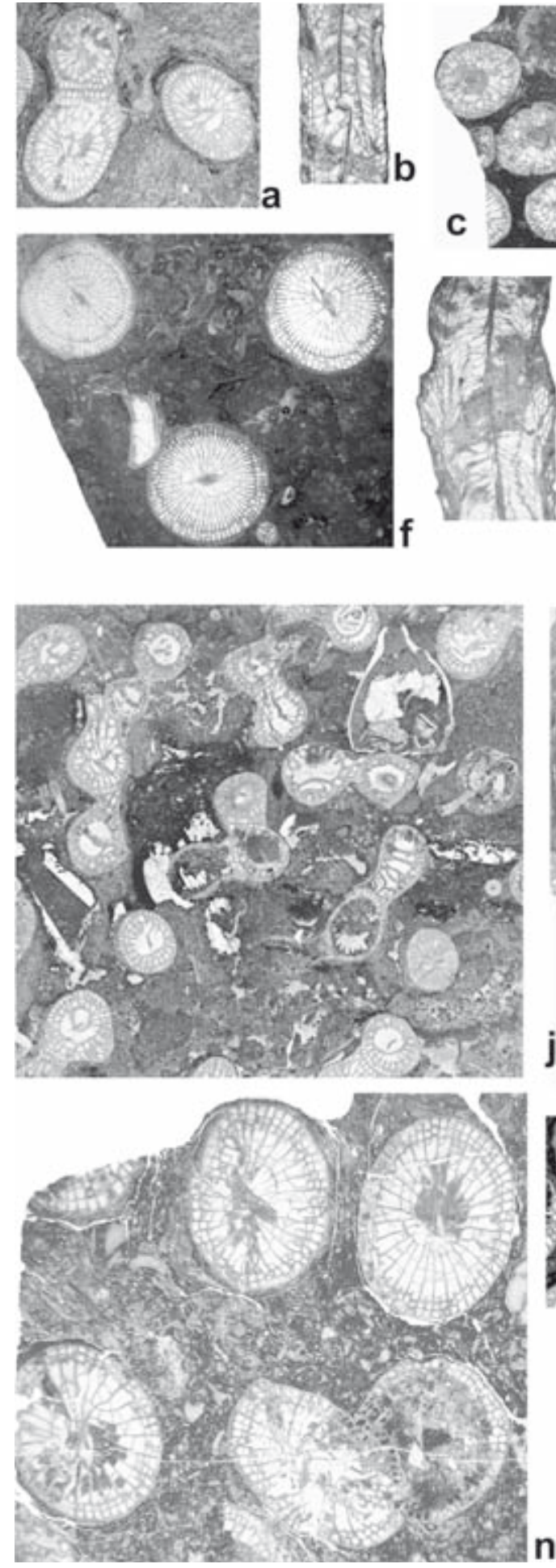
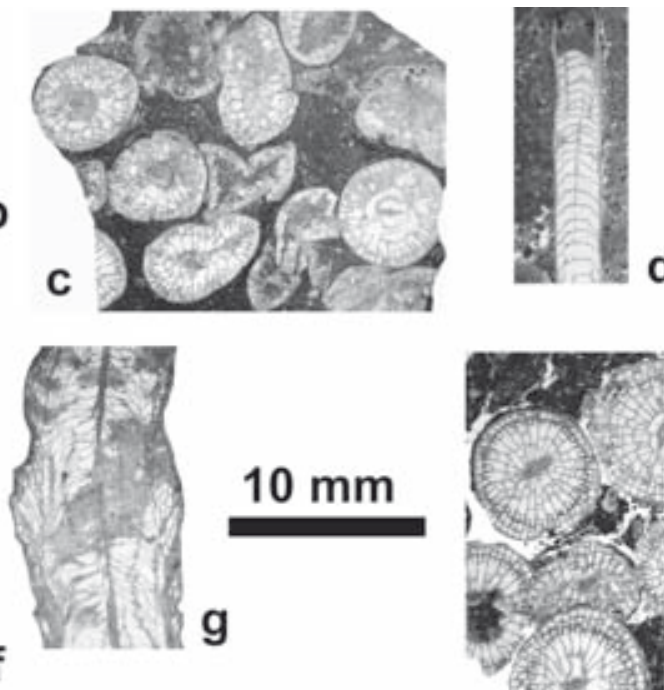
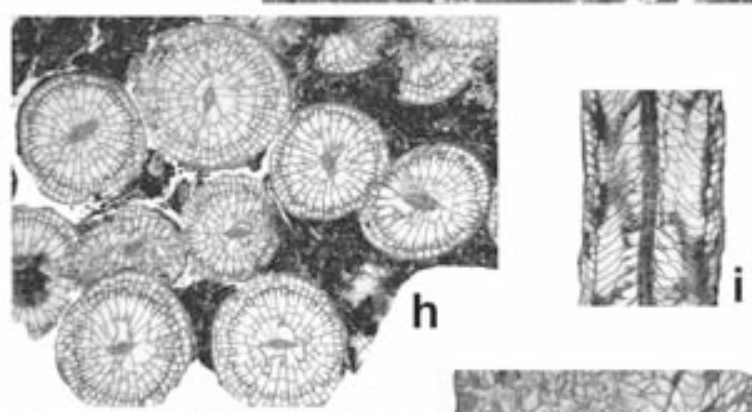
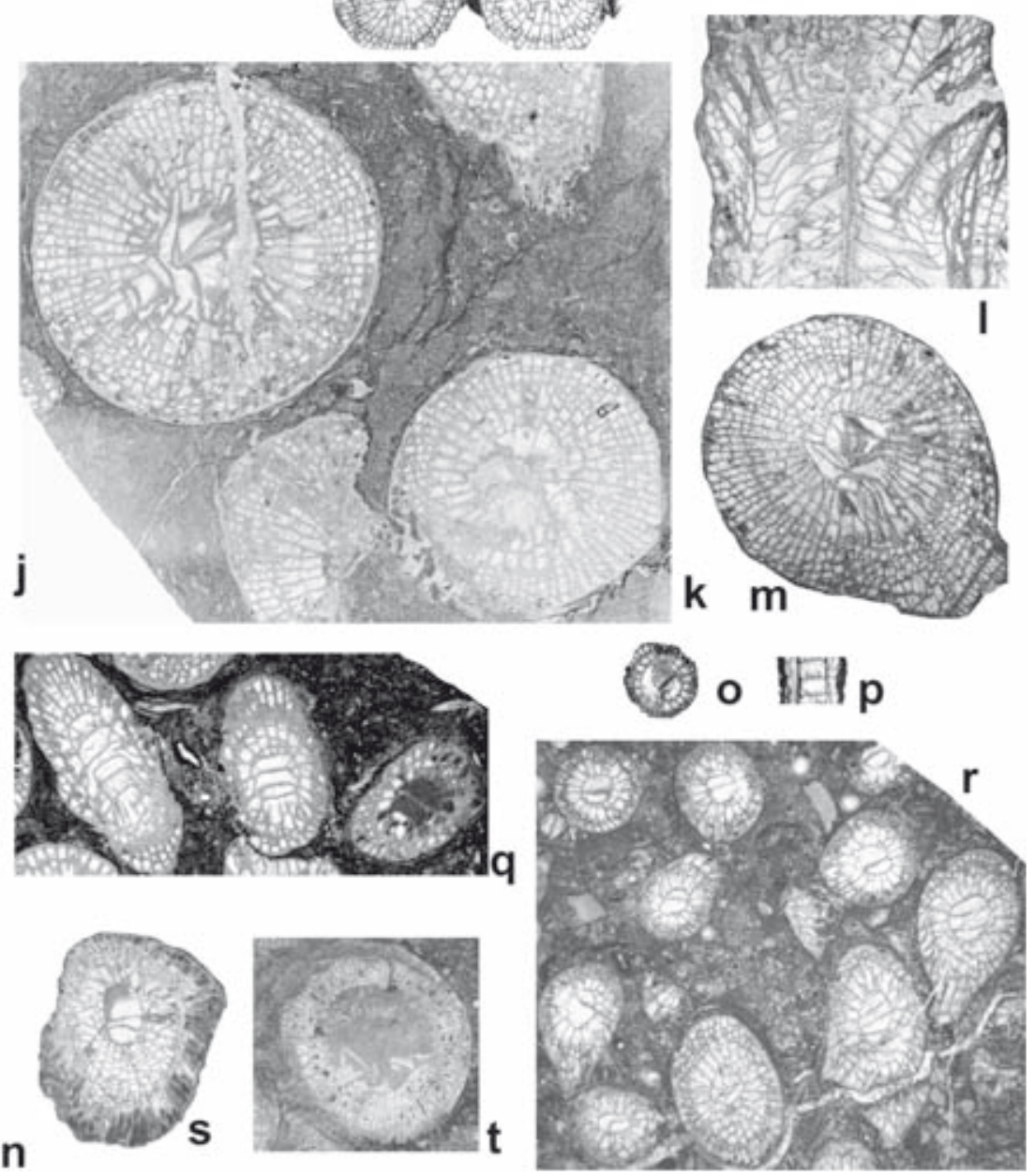

Figure 9. Fasciculate lithostrotionids. a-b) Siphonodendron intermedium. Specimen CCS/8-1, Cantera Castillo, (a) transverse section; (b) longitudinal section. c) Siphonodendron irregulare. Specimen COL/14-7, El Collado, transverse section. d-e) Siphonodendron junceum. Specimen CCS/11-1, Cantera Castillo, (d) longitudinal section; (e) transverse section. f-g) Siphonodendron kleffense. Specimen CAÑ/1-14, El Cañal, (f) transverse section; (g) longitudinal section. h-i) Siphonodendron martini. Specimen PÑR/1-1, Peñarroya, transverse section. (h) transverse section; (i) longitudinal section. j) Siphonodendron pauciradiale. Specimen SSE2/18-9, Sierra de la Estrella 2, transverse section. k-m) Siphonodendron scaleberense. Specimen SSE/141, Sierra del Estrella 1. (k, m) transverse sections; (I) longitudinal section. n) Siphonodendron sociale. Specimen COL/53, El Collado, transverse section. o-p) Diphyphyllum gracile. Specimen PÑR/2-2, Peñarroya, (o) transverse section; (p) longitudinal section. q) Diphyphyllum furcatum. Specimen CAÑ0/17, El Cañal, oblique section. r) Solenodendron furcatum. Specimen CAÑ0/7, El Cañal, transverse section. s) Solenodendron horsfieldi. Specimen COL/3-4, El Collado, transverse section. t) Tizraia sp. Specimen CAÑ0/5, El Cañal, transverse section. Scale bar same for all pictures. 
Diagnosis (after Rodríguez \& Somerville, 2014). Solitary corals. Septa of two orders, thick in periphery, where they may be interrupted in adult stage by transeptal dissepiments. Axial structure composed of thickened, irregular and anastomosing radial lamellae, crossed by a median plate. Conical axial tabellae, concave or subhorizontal periaxial tabellae. Microstructure of the wall is lamellar; septa with fibrous mesoplasm and lamellar stereoplasm.

\section{Axophyllum kirsopianum (Thomson \& Nicholson, 1876)}

(Fig. 10a)

Diagnosis (after Rodríguez \& Somerville, 2014). Axophyllum 18 to $22 \mathrm{~mm}$ in diameter, $14-16 \mathrm{~mm}$ in tabularium diameter, 6-7 $\mathrm{mm}$ in axial structure diameter, having 41 to 46 septa of two orders. Majors thick and withdrawn from the axial structure. Low development of lonsdaleoid dissepiments. Inner wall composed of thickened dissepiments. Axial structure large $(1 / 3$ of the diameter) and showing thick septal lamellae. Fibrous septal mesoplasm, lamellar stereoplasm.

Distribution. Known from olistolites from El Casar, Fuenteobejuna, Peñarroya, Castillo Belmez, Sierra Palacios, La Juliana-San Antonio, La Adelfilla and Cerro Cabello.

\section{Age. Brigantian.}

\section{Axophyllum pseudokirsopianum Semenoff-Tian- Chansky, 1974 \\ (Figs 10b-10c)}

Diagnosis (after Rodríguez \& Somerville, 2014). Large Axophyllum, having 35-50 septa of two orders in 22-31 $\mathrm{mm}$ in diameter, $15-20 \mathrm{~mm}$ in tabularium diameter, and $7-13 \mathrm{~mm}$ in axial structure diameter. Majors thick in the peripheral part, thinning to the axis. Minors long. Low development of lonsdaleoid dissepiments. Inner wall composed of thickened dissepiments. Axial structure large (1/3 of the diameter) and showing thick septal lamellae. Fibrous septal mesoplasm, lamellar stereoplasm.

Distribution. Recorded in olistolites from Fuenteobejuna, Casa de la Calera, Peñarroya, El Cañal, and the Antolín Section, El Castillo Unit.

Age. Brigantian.

$$
\text { Axophyllum mendipense (Sibly, 1906) }
$$

(Fig. 10d)

Diagnosis (after Rodríguez \& Somerville, 2014). Axophyllum, having 25-35 septa of two orders in 10-20 $\mathrm{mm}$ in diameter, $8-15 \mathrm{~mm}$ in tabularium diameter, and
4-8 $\mathrm{mm}$ in axial structure diameter. Majors thick. Minors short, form crests on the dissepiments and wall. Low development of lonsdaleoid dissepiments in a narrow dissepimentarium. Inner wall composed of thickened dissepiments. Axial structure $1 / 3$ to $1 / 4$ of the diameter. It shows a dense net composed of thick septal lamellae and conical axial tabellae. Fibrous septal mesoplasm, lamellar stereoplasm.

Distribution. Recorded in sections of Antolín, El Couce and El Collado, El Castillo Unit.

Age. Brigantian.

$$
\text { Axophyllum densum (Ryder, 1930) }
$$

(Figs 10e-10f)

Diagnosis (after Rodríguez \& Somerville, 2014). Axophyllum, having 20-34 septa of two orders in 5-15 mm in diameter, $4-13 \mathrm{~mm}$ in tabularium diameter, and 2-3 $\mathrm{mm}$ in axial structure diameter. Majors almost reaching the axial structure. Thick septal stereozone in young stages that is interrupted by a few lonsdaleoid dissepiments in adult stage. Axial structure $1 / 3$ to $1 / 5$ of the diameter. Fibrous septal mesoplasm, lamellar stereoplasm.

Distribution. Recorded in Cantera Castillo, El Collado, El Cañal, and Peñarroya sections.

Age. Upper Asbian and lower Brigantian.

$$
\text { Axophyllum vaughani (Salée, 1913) }
$$

(Fig. 10g)

Diagnosis (after Rodríguez \& Somerville, 2014). Axophyllum, having 25-36 septa of two orders in 12-16.5 $\mathrm{mm}$ in diameter, $7-10 \mathrm{~mm}$ in tabularium diameter, and 3-4 $\mathrm{mm}$ in axial structure diameter. Majors reaching or almost reaching the axial structure. Minors short to absent. Dissepimentarium showing moderate development of the lonsdaleoid dissepiments. Axial structure $1 / 3$ to $1 / 5$ of the diameter. Fibrous septal mesoplasm, lamellar stereoplasm.

Distribution. Recorded in El Collado, El Casar and Peñarroya sections.

Age. Upper Asbian and lower Brigantian.

Axophyllum tazoultense Semenoff-Tian-Chansky, 1974 (Fig. 10h)

Diagnosis (after Rodríguez \& Somerville, 2014). Axophyllum, having 40-47 septa of two orders in 14-20 $\mathrm{mm}$ in diameter, $12-14 \mathrm{~mm}$ in tabularium diameter, and $7-8 \mathrm{~mm}$ in axial structure diameter. Majors reaching or 
almost reaching the axial structure. Minors penetrating into the tabularium. Dissepimentarium showing interseptal dissepiments, lonsdaleoid dissepiments if present (eroded in the type). Axial structure large, with irregular median plate; densely packed in the periphery, loosely packed in the axis. Axial tabellae gently declined towards the periphery in the axis, but steeply declined in the periphery. Periaxial tabellae concave and declined towards the axis. Fibrous septal mesoplasm, lamellar stereoplasm.

Distribution. Recorded in El Casar.

Age. Brigantian.

Axophyllum spiralum Rodríguez \& Somerville, 2014 (Fig. 10i)

Diagnosis (after Rodríguez \& Somerville, 2014). Axophyllum, having 30-38 majors in 10-20 $\mathrm{mm}$ in diameter, $8-18 \mathrm{~mm}$ in tabularium diameter, and $4-8 \mathrm{~mm}$ in axial structure diameter. Majors reaching or almost reaching the axial structure. Minors short, penetrating slightly into the tabularium. Narrow dissepimentarium only developed in adult stages showing lonsdaleoid dissepiments and one row of thickened interseptal dissepiments that form a conspicuous inner wall. Axial structure large (1/2 to $1 / 3$ of the diameter), with irregular median plate, thick, anastomosed and twisted radial lamellae and thin conical tabellae. Periaxial tabellae concave and declined towards the axis. Fibrous septal mesoplasm, lamellar stereoplasm.

Distribution. El Casar, Fuenteobejuna and Peñarroya sections.

Age. Brigantian.

Axophyllum cozari Rodríguez \& Somerville, 2014 (Figs 10j-10k)

Diagnosis (after Rodríguez \& Somerville, 2014). Axophyllum, having 34-39 majors in 24-32 $\mathrm{mm}$ in diameter, $16-18 \mathrm{~mm}$ in tabularium diameter, and 7-9 $\mathrm{mm}$ in axial structure diameter. Majors reaching or almost reaching the axial structure. Minors long, penetrating clearly into the tabularium. Wide lonsdaleoid dissepimentarium and one to three rows of interseptal dissepiments; the inner one forms a conspicuous inner wall. Axial structure $1 / 3$ to $1 / 4$ of the alar diameter, with strongly thickened median plate, thick, anastomosed and twisted radial lamellae and conical tabellae. Periaxial tabellae concave and declined to the axis. Fibrous septal mesoplasm, lamellar stereoplasm.

Distribution. Antolín Section, Córdoba Province, Sierra Boyera Block.
Age. Brigantian.

Genus Gangamophyllum Gorsky, 1938

Type species Gangamophyllum boreale Gorsky, 1938

Diagnosis (modified from Semenoff-Tian-Chansky, 1974). Solitary conical corals having a peripheral zone of large dissepiments sometimes lonsdaleoid. Inner wall that is reduced in adult stages. Web-like axial structure without median plate, composed of radial lamellae and axial tabellae. Large dissepiments very declined towards the axis. Periaxial tabellae concave and also declined towards the axis. Domical axial tabellae. Fibronormal mesoplasm, lamellar stereoplasm.

\section{Gangamophyllum gorskyi Vassiljuk, 1960}

(Fig. 101)

Diagnosis (after Rodríguez \& Somerville, 2014). Gangamophyllum 20 to $25 \mathrm{~mm}$ in diameter, $13-15 \mathrm{~mm}$ in tabularium diameter, 7.5-9 $\mathrm{mm}$ in axial structure diameter, having 36 to 40 septa of two orders. Majors thick and in contact with the axial structure. Dissepiments mainly regular to herringbone. Conspicuous inner wall composed of thickened dissepiments. Axial structure large (1/3 of the diameter), showing thick, slightly twisted septal lamellae. Fibrous septal mesoplasm, lamellar stereoplasm.

Distribution. Recorded in Fuenteobejuna, Peñarroya, Sierra Palacios, Adelfilla Quarry and Cerro Cabello.

Age. Brigantian.

Gangamophyllum mosquense Dobrolyubova, 1952

(Fig. 10m)

Diagnosis (after Rodríguez \& Somerville, 2014). Gangamophyllum 28 to $34 \mathrm{~mm}$ in diameter, $11-15 \mathrm{~mm}$ in tabularium diameter, 5-8 $\mathrm{mm}$ in axial structure diameter, having 28 to 34 septa of two orders. Majors thick to moderately thick and long, almost reaching the axial structure. Minors mainly small crests on the inner wall. Wide lonsdaleoid dissepimentarium composed of large elongated dissepiments. Inner row thickened to form an inner wall. Axial structure large (about $1 / 3$ of the diameter), showing low density of thin radial lamellae and axial tabellae. Fibrous septal mesoplasm, lamellar stereoplasm.

Distribution. Recorded in El Casar and El Collado.

Age. Brigantian.

Genus Morenaphyllum Rodríguez \& Somerville, 2014

Type species Morenaphyllum antolinense Rodríguez \& Somerville, 2014 
Diagnosis. Axophyllinae with quite a small axial structure joined to a thick and long cardinal septum and having an irregular median plate, which is thick, but discontinuous, a few radial lamellae and conical tabellae. Conspicuous inner wall composed of lamellar thickenings. Wide transeptal dissepimentarium. Mesoplasm composed of bundles of microlamellae that comprise pseudofibrous structures that produce characteristic denticulations on the wall and transeptal dissepiments. Lamellar stereoplasm.

\section{Morenaphyllum antolinense Rodríguez \& Somerville, 2014 \\ (Figs 10n-10p)}

Diagnosis. Morenaphyllum having a thick wall and low development of stereoplasmatic thickenings. 30 to 40 majors in 18 to $28 \mathrm{~mm}$ in adult stages. Axial structure 2.5-5 $\mathrm{mm}$, being $1 / 5$ to $1 / 7$ of the diameter.

Location, horizon and age. Antolín section, located near the coal mine of Antolín, $2 \mathrm{~km}$ south from Peñarroya. Sierra Boyera Block, El Castillo Unit.

Age. Brigantian.

\section{Morenaphyllum boyerense Rodríguez \& Somerville, 2014 \\ (Figs 10q-10r)}

Diagnosis. Morenaphyllum having 30 to 34 majors in 18 to $20 \mathrm{~mm}$ in diameter, counter septum commonly joined to the axial structure, strong stereoplasmatic thickenings and irregular inner wall. Axial structure 2-3 $\mathrm{mm}$ being 1/6 of the diameter.

Distribution. Antolín section, located near the coal mine of Antolín, $2 \mathrm{~km}$ south from Peñarroya. Sierra Boyera Block, El Castillo Unit.

Age. Brigantian.

\section{Morenaphyllum sp.}

(Fig. 10s)

Distribution. Fuenteobejuna outcrop. Sierra Boyera Block, El Castillo Unit.

Age. Brigantian.

Family Geyerophyllidae Grabau, 1930

Genus Amygdalophylloides Dobrolyubova \& Kabakovich, 1948

Type species Amygdalophylloides ivanovi Dobrolyubova, 1937
Diagnosis (modified from de Groot, 1963). Small, solitary geyerophyllid corals with septa typically extending from the epitheca; dissepimentarium narrow and mainly interseptal; axial structure formed chiefly by the dilated and vertically elongated axial end of the cardinal septum, that may be reinforced by some septal lamellae and tabellae.

Amygdalophylloides anticuum Rodríguez \& Said, 2009 (Figs 10t-10v)

Diagnosis (after Rodríguez \& Said, 2009). Small, solitary, ceratoid corals having 25 to 28 majors and 5.5 to $8 \mathrm{~mm}$ in diameter. Thin septa that almost reach the axial structure. This is a large, massive, oval column that may show irregular borders. Well developed clinotabulae, deeply declined towards the column. Septal stereozone in young stages, which is substituted in adult stages by one or two rows of mainly transeptal dissepiments. Septal microstructure composed of small fibres grouped in fascicles; lamellar microstructure of wall and thickenings of septa and axial column.

Distribution. El Casar, Fuenteobejuna, Peñarroya, Casa de la Calera, El Cañal, San Antonio-La Juliana Unit olistolites and Sierra Boyera Block (Sierra del Castillo Unit).

Age. Brigantian.

Order HETEROCORALLIA Schindewolf, 1941

Family Heterophylliidae Dybowski, 1873

Genus Hexaphyllia Stuckenberg, 1904

Type species Hexaphyllia prismatica Stuckenberg, 1904

Diagnosis (after Cossey, 1997). Elongate, cylindrical or prismatic heterocorals with up to six sides and a maximum of six septa, which meet at or near the axis. The peripheral edges of the septa may thicken and project through the wall to form longitudinal ridges or costae along the side of the corallite. The costae may be adorned with tubercles or spines which curve distally in the direction of corallite growth. Whilst the internal structure of the costae, spines and tubercles appears to be continuous with the septa, their external structure appears to form an extension of the tabulotheca. The tabulae are complete and slightly domed structures near the axis, but turn downwards peripherally and fuse together between the distal edges of the septa to form the tabulotheca. Corallite diameters and tabulae spacing values are continuously variable parameters.

\section{Hexaphyllia marginata (Fleming, 1823)}

(Fig. 11a) 

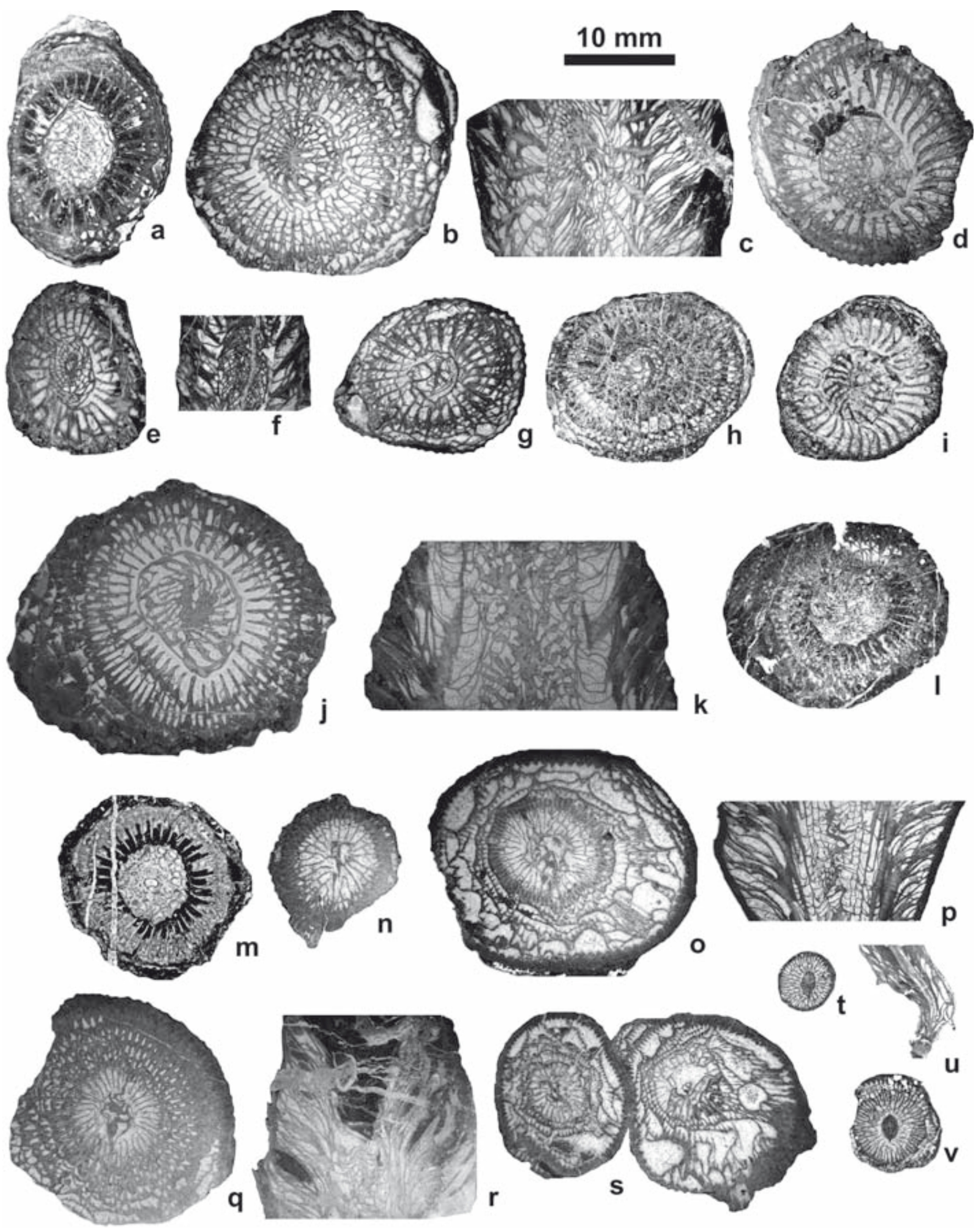
Diagnosis (after Cossey, 1997). As for the genus.

Distribution. Recorded from Antolín, Cantera Castillo and El Collado, Sierra del Castillo Unit.

Age. Asbian-Brigantian.

Genus Heterophyllia McCoy, 1849

Type species Heterophyllia grandis McCoy, 1849

Diagnosis (modified from Poty, 1981). Solitary corals, sub-cylindrical, very long, with crests sometimes prolongated by spines. Septa grouped in fascicles, crossing the external wall. Septa divided dichotomously from the axial oblique plate. Tabulae strongly domical. Absence of dissepiments. Absence of calice.

\section{Heterophyllia ornata McCoy, 1849}

(Fig. 11b)

Diagnosis (modified from Poty, 1981). Heterophyllia that may reach several tens of $\mathrm{cm}$ in length but does not exceed $4.2 \mathrm{~mm}$ in diameter and having a maximum of 30 septa.

Distribution. Recorded from Antolín, El Cañal and El Collado, Sierra del Castillo Unit.

Age. Brigantian.

Subclass TABULATA Milne-Edwards \& Haime, 1850 Order SYRINGOPORIDA Sokolov, 1947

Family Syringoporidae de Fromentel, 1861

Subfamily Syringoporinae de Fromentel, 1861

Genus Syringopora Goldfuss, 1826

Type species Syringopora ramulosa Goldfuss, 1826

Diagnosis (after Tchudinova, 1986). Colony fasciculate, with closely spaced, occasionally contiguous cylindrical corallites. Corallites long, usually more or less curved, but on the whole parallel to each other. Corallite wall externally covered with concentrically rugose or smooth epitheca. Microstructure of wall lamellar. Corallites connected by tubules that are usually horizontal and irregularly arranged. Tabulae infundibuliform, with or without axial syrinx. Septal elements appearing as longitudinal rows of spinules. Microstructure of lamellar spinules, less commonly trabecular (monacanths, holacanths). Increase lateral or solenial (offsets appear on connecting tubules).

Remarks. The auloporoids from Guadiato Area have been described by Coronado \& Rodríguez (2014) in open nomenclature, awaiting a more detailed revision that is in preparation. Thus, all species are referred in this paper to the nomenclature given in the cited article (sp. A, B, C, etc.).

\section{Syringopora sp. B (Coronado \& Rodríguez, 2014)} (Figs 11c-11d)

Distribution. Recorded from Antolín, El Cañal and La Adelfilla, Sierra del Castillo and San Antonio-La Juliana units.

\section{Age. Brigantian.}

Family Multithecoporidae Sokolov, 1950

Genus Multithecopora Yoh, 1927

Type species Multithecopora penchiensis Yoh, 1927

Diagnosis (after Tchudinova, 1986). Colonies fasciculate, with cylindrical corallites bearing welldefined wrinkled epitheca. Sclerenchyme of wall lamellar and so thick that lumen of corallites reduced to $1 / 3-1 / 5$ of diameter; epitheca fibrous. Connecting tubules thin, sparse; mural pores developed where corallites contact. Tabulae thin, complete, horizontal, concave, sparse, in places absent. Septal spinules well developed or lacking. Increase interstitial, more commonly lateral.

Figure 10. Axophyllidae and Geyerophyllidae. a) Axophyllum kirsopianum. Specimen CS/11-4, El Casar, transverse section. b-c) Axophyllum pseudokirsopianum. Specimen PÑR/4-14, Peñarroya, (b) transverse section; (c) longitudinal section. d) Axophyllum mendipense. Specimen COL/7-8, El Collado, transverse section. e-f) Axophyllum densum. Specimen CCS/119, Cantera Castillo, (e) transverse section; (f) longitudinal section. g) Axophyllum vaughani. Specimen CS/14-15, El Casar, transverse section. h) Axophyllum tazoultense. Specimen CS/12-3, El Casar, transverse section. i) Axophyllum spiralum. Specimen CS/15-2, El Casar, transverse section. j-k) Axophyllum cozari. Specimen ANT2/1-39, Antolín, (j) transverse section; (k) longitudinal section. l) Gangamophyllum gorskyi. Specimen ADF/5-11, La Adelfilla, transverse section. m) Gangamophyllum mosquense. Specimen CS/25-5, El Casar, transverse section. n-p) Morenaphyllum antolinense. (n) Specimen ANT2/1-1, Antolín, transverse section in young stage. (o-p) Specimen ANT2/2-52, Antolín, transverse and longitudinal sections. q-r) Morenaphyllum boyerense. Specimen ANT2/2-12, Antolín, (q) transverse section; (r) longitudinal section. s) Morenaphyllum sp. Specimen FBJ/35, Fuenteobejuna, transverse section. t-v) Amygdalophylloides anticuum. (t, v) Specimen CS/7-36, El Casar, transverse sections in young and adult stages respectively. (u) Specimen CS/7-6, El Casar, longitudinal section. Scale bar same for all pictures. 

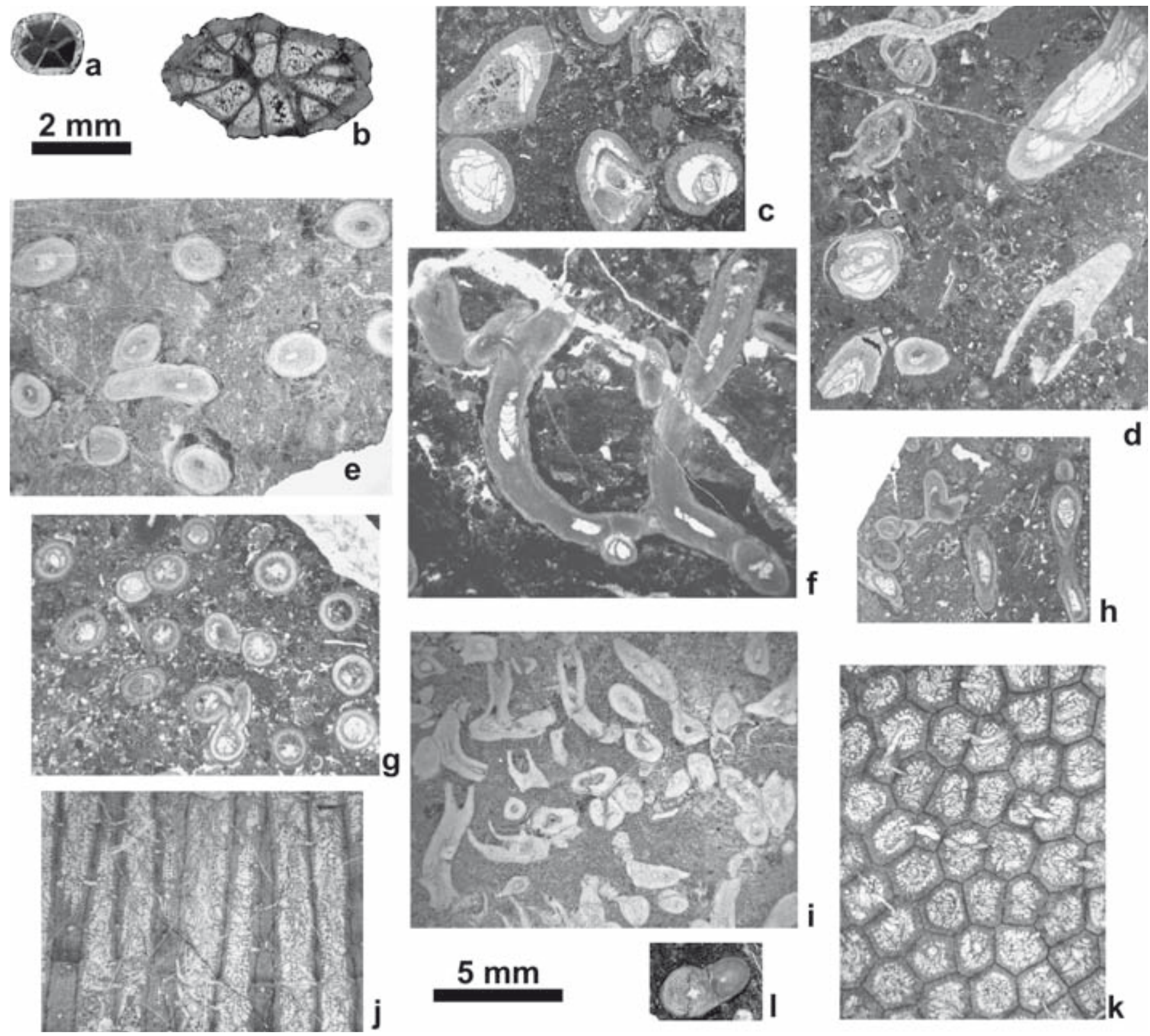

Figure 11. Heterocorallia and Tabulata. a) Hexaphylia marginata. Specimen CAÑO0/22, El Cañal, transverse section. b) Heterophyllia ornata. Specimen CAÑ0/25, El Cañal, transverse section. c-d) Syringopora sp. B from ANT, Antolín, (c) transverse sections. (d) transverse and oblique sections. e-f) Multithecopora sp. A from ANT, Antolín, (e) transverse sections; (f) longitudinal sections. g-h) Multithecopora sp. B from FBJ, Fuenteobejuna, (g) transverse section; (h) oblique and longitudinal sections. i) Multithecopora sp. C. from COL, El Collado, transverse and longitudinal sections. j-k) Roemeripora sp. from FBJ, Fuenteobejuna. (j) longitudinal section; (k) transverse section. l) Cladochonus sp. from COL, El Collado, oblique section. $2 \mathrm{~mm}$ scale bar for heterocorals, $5 \mathrm{~mm}$ scale bar for tabulates.

Multithecopora sp. A (Coronado \& Rodríguez, 2014) (Figs 11e-11f)

Distribution. Recorded from Fuenteobejuna, Antolín, El Cañal, El Collado and Sierra de la Estrella 1, Sierra del Castillo and San Antonio-La Juliana units.

Age. Asbian-Brigantian.
Multithecopora sp. B (Coronado \& Rodríguez, 2014) (Figs 11g-11h)

Distribution. Recorded from Fuenteobejuna, Antolín and El Cañal, Sierra del Castillo and San Antonio-La Juliana units.

Age. Asbian-Brigantian. 
Multithecopora sp. C (Coronado \& Rodríguez, 2014) (Fig.11i)

Distribution. Recorded from El Collado, Sierra del Castillo unit.

Age. Lowermost Brigantian.

Family Syringolitidae Waagen \& Wentzel, 1886

Genus Roemeripora Kraicz, 1934

Type species Roemeripora bohemica (Pocta, 1902)

Diagnosis (after Hill, 1981). Corallum cerioid; corallites prismatic or, when slightly divergent, cylindrical; peripheral stereozone transversely wrinkled externally where corallites are not tightly adpressed; septal spines holacanthine, arranged in lamellar sclerenchyma of stereozone in numerous radial longitudinal rows and on tabulae; tabulae thin, complete, or more commonly incomplete, horizontal, concave or infundibuliform, and grouped in relation to pore-canals (or to connecting tubules that lie on the external wrinklings of the wall); offsets arise from openings of pore-canals.

\section{Roemeripora sp.}

(Figs 11j-11k)

Distribution. Recorded from Fuenteobejuna, San Antonio-La Juliana unit.

Age. Brigantian.

Family Pirgiidae de Fromentel, 1861

Genus Cladochonus McCoy, 1847

Type species Cladochonus tenuicollis McCoy, 1847

Diagnosis (after Hill, 1981). Proxima1 parts of corallum prostrate, annular when externally attached to crinoid stem; distal parts of corallum erect branches that may torque; corallites commonly opening through wall near base of calice of parent; wall moderately thick, in some states of preservation including holacanthine spinules; in other states, growth lamellae of sclerenchyme of wall may be slightly separate and connected by granules; tabulae absent or sparse.

\section{Cladochonus sp.}

(Fig. 111)

Distribution. Recorded from El Collado, Sierra del Castillo unit.

Age. Lowermost Brigantian.

\section{DISCUSSION}

\subsection{Diversity and abundance}

The number of species illustrated in this inventory (69) is not the result of a really high coral abundance and/or diversity in the Guadiato Area. The studied area covers more than $150 \mathrm{~km}^{2}$ of which about $30 \mathrm{~km}^{2}$ are limestones. In addition, it comprises a time span of more than 5 million years in a subtropical region (Golonka, 2012). Comparing with recent parameters, the presence of several hundreds of coral species could be expected. There are many reasons for the reduced recorded diversity:

1) The coral record is not complete and some species that lived in that area may be not preserved.

2) Our coral taxonomy is basically morphologic. The corals are primitive invertebrates in which many homeomorphic processes take place. The identification of several true species as a single morphological species is highly probable (Fedorowski, 2010).

3) Sedimentation took place in a syntectonic environment. The Variscan Orogeny produced the collision of Gondwana and Laurasia and the Iberian plate was located in the middle of that collision (Wagner, 1999, 2004). The most abundant sediments in the Guadiato Area are siliciclastics. In many cases, limestones are interbedded with shales and sandstones; the siliciclastic inputs created environments not favourable for corals. In addition, tectonic movements also destroyed part of the carbonate platforms, as proved by the presence of Viséan limestone olistolites in Serpukhovian rocks of the San Antonio-La Juliana Unit (Gabaldón et al., 1985a; Cózar \& Rodríguez, 1999a).

However, the number of species recorded for the same time span is not much lower than those from other wellknown regions. The inventory of Mississippian rugose corals from Belgium (Denayer et al., 2011), provide an excellent database for comparison. The stratigraphic interval, comprises the coral zones RC6 to RC8 (Poty, 1984; Poty et al., 2006; Denayer et al., 2011) in Belgium and the coral zones 1 to 5 (Rodríguez \& Somerville, 2007). For that stratigraphic interval, 74 rugose coral species have been recorded in Belgium and 61 in the Guadiato Area. Taking into account that the Belgian outcrops are by far more extensive, were located closer to the Equator and have been studied for many more years than those from the Guadiato, the difference is not significant. No similar synthesis or inventories have been done in other regions, but 43 rugose coral species have been recorded by Mitchell (1989) in Britain without taking into account the zaphrentid corals and only with his own data (based mostly on Viséan taxa). The degree of diversity in all those areas from the western Palaeotethys seems to be similar. 
Comparisons with other areas can not be achieved, because no detailed inventories have been done. However, the different degree of knowledge of Viséan coral records in regions such as Poland (Fedorowski, 1968, 1971, 1975; Khoa, 1977, etc.), Donets Basin (Vassiljuk, 1960), Béchar and Tindouf basins in Sahara (Semenoff-TianChansky,1974, 1985; Aretz, 2011; Rodríguez et al., 2013) and Azrou-Khenifra Basin in Morocco (Said et al., 2007, 2013; Aretz \& Herbig, 2010) give similar results when the coral assemblages have been extensively studied.

The conclusion is that the coral diversity in the Guadiato Area is standard for the western Palaeotethys. However, very few outcrops and/or beds yielded a high number of species (Table 1). The exceptions to that rule are of two types: 1) Outcrops such as Antolín (19 species recorded) and El Cañal (23 species recorded) where the corals are located mainly in debris coming from shallow platforms, but sedimented in deeper water facies. These outcrops comprise sediments coming from different environments (reefs, calcareous shoals, shallow and middle platform), that are reworked and concentrated. The assemblages are highly diverse, because they are mixed associations that comprise elements of several environments. 2) Thick sections that comprise more than 100 metres of limestones, such as Cantera Castillo (17 species), El Collado (32 species) and Sierra de la Estrella 1 (19 species). They thus correspond to temporal accumulations.

Corals are mostly scarce in the Guadiato Area. They are abundant only in some precise beds, related to reefal development. Antolín and El Cañal debris show conspicuous concentration of corals, where lithostrotionids and syringoporoids are dominant. El Collado-2 bed (Rodríguez et al., 2007) is a coral biostrome partially reworked by a storm. No other bed shows a high abundance of corals. They are also common in some beds at Sierra de la Estrella, in La Adelfilla, in Fuenteobejuna, Peñarroya and in El Casar. It is a result of the scarcity of appropriate environments for the development of corals.

The level of endemism is low, as it is usual in the western Palaeotethys. Two genera (Espielia and Morenaphyllum) have been described for the first time in the Viséan from the Guadiato Area, but at least one of them (Espielia) has been subsequently found in South France (Aretz, 2002) North Africa (Aretz, 2011) and Turkey (Denayer, 2012). A possible species of Morenaphyllum was previously described by Bykova (1966) under the generic name of Carcinophyllum. Seven species have been first described in the Guadiato Area (Amygdalophylloides anticuum, Axophyllum cozari, Axophyllum julianaense, Axophyllum spiralum, Espielia columellata, Morenaphyllum antolinense and Morenaphyllum boyerense). As one of them has been also recorded in other areas, the level of endemism is lower than $10 \%$.

\subsection{Environments}

The coral assemblages from the Guadiato Area show clear differences in different environments. In such a large region and with so many outcrops, very different environments where corals lived have been recorded, from very shallow-water platforms and reefs to deeper water middle ramps. The analysis of the environments where the coral lived in the Guadiato Area was achieved by Rodríguez \& Somerville (2007) and it will be not repeated here. A more general analysis on Mississippian coral habitats was achieved by Aretz (2010). A summary of the environments of each outcrop including main microfacies is shown in Table 2.

The outcrops located in the different blocks of the Sierra del Castillo Unit are usually sections that comprise various facies and coral assemblages. They are diverse environments recorded in those outcrops:

\subsubsection{Sierra del Castillo Unit}

Most corals recorded in outcrops from the Sierra Boyera Block (Casa de la Calera, Antolín, El Cañal and Sierra Boyera) are located in debris sedimented in ramp/talus that comprise assemblages coming from shallower-water facies (Cózar \& Rodríguez, 2000; Rodríguez \& RodríguezCurt, 2002), which include shallow platforms, reefs and shoals. The outcrop from El Couce Block shows clearly a Cyathaxonia fauna assemblage, typical of a deeper water distal shelf or slope. The Assemblages from the Sierra del Castillo Block comprise thick sequences, with very diverse environments (Cózar \& Rodríguez, 1999c; Rodríguez et al., 2007). The Cantera Castillo and El Collado sections comprise mainly shallow shelf environments, whereas Sierra de la Estrella 1 and 2 comprise mainly middle and distal deeper water ramp facies including microbial mudmounds (Cózar et al., 2003).

\subsubsection{San Antonio-La Juliana Unit}

All Viséan outcrops in that unit represent olistoliths that show a very homogeneous facies; bioclastic wackestones/ packstones representing shallow platform environments, and ooidal grainstones representing shoals. It is also the case of the olistoliths mentioned here (Castillo Belmez, Sierra Palacios, Burjadillo, La Juliana, La Adelfilla and Cerro Cabello).

\subsubsection{North-western outcrops}

The outcrops located in the north-western end of the Guadiato Area (Peñarroya, Fuenteobejuna; Fig. 2) and its prolongation (El Casar; Fig. 3) are bounded by faults and can not be regarded as part of either the San AntonioLa Juliana or Sierra del Castillo units. Their positioning seems to indicate that they are a prolongation of the line of olistoliths, but the coral assemblages are closer to 
Table 2. Environmental parameters of the studied outcrops. Abbreviation RCA is Rugose Coral Assemblages of Somerville \& Rodríguez (2007).

\begin{tabular}{|c|c|c|c|c|c|c|c|}
\hline Outcrops and units & $\begin{array}{l}\text { RCA } \\
\text { (S \& R } 007\end{array}$ & & $\begin{array}{l}\text { Main } \\
\text { microfacies }\end{array}$ & Main coral taxa & Abundance & $\begin{array}{l}\text { Transport } \\
\text { index }\end{array}$ & Observations \\
\hline El Casar & RCA2 & & Packstone & $\begin{array}{l}\text { Axophyllum, Palaeosmilia, } \\
\text { Amygdalophylloides }\end{array}$ & Moderate & Moderate & \\
\hline Fuenteobejuna & $\mathrm{RCA} 2$ & & $\begin{array}{l}\text { Packstone, } \\
\text { Grainstone }\end{array}$ & $\begin{array}{l}\text { Axophyllum, Syringoporoids, } \\
\text { Amygdalophylloides }\end{array}$ & Moderate & Moderate & \\
\hline Peñarroya & $\mathrm{RCA} 2$ & & $\begin{array}{l}\text { Packstone, } \\
\text { Grainstone }\end{array}$ & $\begin{array}{l}\text { Axophyllum, Palaeosmilia, } \\
\text { Amygdalophylloides }\end{array}$ & Low to moderate & Moderate & \\
\hline Casa de la Calera & $\mathrm{RCA} 2$ & & $\begin{array}{l}\text { Packstone, } \\
\text { Boundstone }\end{array}$ & $\begin{array}{l}\text { Axophyllum, Palaeosmilia, } \\
\text { Amygdalophylloides }\end{array}$ & Low to moderate & High & \\
\hline Antolín 1 & $\mathrm{RCA} 7$ & & $\begin{array}{l}\text { Rudst one, } \\
\text { Boundstone }\end{array}$ & $\begin{array}{l}\text { Siphonodendron, Lithostrotion, } \\
\text { Syringoporoids }\end{array}$ & High & Very high & $\begin{array}{l}\mathrm{R} \text { e w o r k e d } \\
\text { assemblage }\end{array}$ \\
\hline Antolín 2 & RCA5 & & Packstone & Axophyllum, Siphonodendron & High & Moderate & \\
\hline Antolín 3 & RCA6 & & $\begin{array}{l}\text { Wackestone, } \\
\text { Marls }\end{array}$ & Siphonophyllia, Caninophyllum & Low & Moderate & \\
\hline El Cañal & $\begin{array}{l}\text { RCA7 } \\
\text { RCA2 }\end{array}$ & + & $\begin{array}{l}\text { Boundstone, } \\
\text { Rudstone }\end{array}$ & $\begin{array}{l}\text { Siphonodendron, Axophyllum, } \\
\text { Syringoporoids }\end{array}$ & Moderate & High & $\begin{array}{l}\text { Mixed and } \\
\text { reworked ass. }\end{array}$ \\
\hline Sierra Boyera & RCA2 & & $\begin{array}{l}\text { Wackestone, } \\
\text { Packstone }\end{array}$ & Clisiophyllum, Palaeosmilia & Low & High & $\begin{array}{l}\text { R e w o r k e d } \\
\text { assemblage }\end{array}$ \\
\hline Castillo Belmez & RCA5 & & $\begin{array}{l}\text { Wackestone, } \\
\text { Packstone }\end{array}$ & Palaeosmilia, Siphonodendron & Low & Moderate & Olistolith \\
\hline Sierra Palacios & $\begin{array}{l}\text { RCA5 } \\
\text { RCA2 }\end{array}$ & + & $\begin{array}{l}\text { Wackestone, } \\
\text { Packstone, } \\
\text { Grainstone }\end{array}$ & Axophyllum, Siphonodendron & Low & Low & Olistolith \\
\hline El Burjadillo & RCA5 & & $\begin{array}{l}\text { Wackestone, } \\
\text { Packstone }\end{array}$ & Siphonodendron, Clisiophyllum & Low & Low & Olistolith \\
\hline La Juliana & RCA5 & & $\begin{array}{l}\text { Wackestone, } \\
\text { Packstone }\end{array}$ & Siphonodendron, Axophyllum, & Moderate & Low & Olistolith \\
\hline El Couce & RCA8 & & Wackestone & $\begin{array}{l}\text { Cyathaxonia, Rotiphyllum, } \\
\text { Ufimia }\end{array}$ & Moderate & Low & \\
\hline $\begin{array}{l}\text { Cantera Castillo (1-4, 6, } \\
14-15)\end{array}$ & RCA2 & & $\begin{array}{l}\text { Wackestone, } \\
\text { Packstone }\end{array}$ & Palaeosmilia, Axophyllum & Moderate & Moderate & \\
\hline Cantera Castillo (8-10) & RCA1 & & Packstone & Aulophyllum, Clisiophyllum & Moderate & Low & \\
\hline Cantera Castillo (11-13) & RCA3 & & $\begin{array}{l}\text { Packstone, } \\
\text { Rudstone }\end{array}$ & Siphonodendron & High & Moderate & Biostrome \\
\hline El Collado (1-3) & $\mathrm{RCA} 3$ & & $\begin{array}{l}\text { Packstone, } \\
\text { Rudstone }\end{array}$ & Siphonodendron & High & Moderate & Biostrome \\
\hline El Collado (4-6) & RCA2 & & $\begin{array}{l}\text { Wackestone, } \\
\text { Packstone }\end{array}$ & Palaeosmilia, Axophyllum & Moderate & Moderate & \\
\hline El Collado (7-13) & RCA5 & & $\begin{array}{l}\text { Wackestone, } \\
\text { Packstone }\end{array}$ & Siphonodendron, Dibunophyllum & Moderate & Moderate & \\
\hline Navacastillo & RCA5 & & $\begin{array}{l}\text { Wackestone, } \\
\text { Packstone }\end{array}$ & Siphonodendron, Dibunophyllum & Low & Moderate & \\
\hline S. Estrella 1 (10-18) & RCA8 & & $\begin{array}{l}\text { Wackestone, } \\
\text { Marls }\end{array}$ & $\begin{array}{l}\text { Rotiphyllum, Cyathaxonia, } \\
\text { Rylstonia }\end{array}$ & Moderate & Low & \\
\hline S. Estrella $1(8-9)$ & RCA6 & & $\begin{array}{l}\text { Wackestone, } \\
\text { Boundstone }\end{array}$ & $\begin{array}{l}\text { Siphonodendron, Siphonophyllia, } \\
\text { Syringoporoids }\end{array}$ & Low & Low & \\
\hline S. Estrella 2 & RCA6 & & $\begin{array}{l}\text { Wackestone, } \\
\text { Packstone }\end{array}$ & Siphonodendron & Low & Low & \\
\hline La Adelfilla & $\begin{array}{l}\text { RCA5 } \\
\text { RCA7 }\end{array}$ & + & $\begin{array}{l}\text { Packstone, } \\
\text { Grainstone }\end{array}$ & Siphonodendron, Axophyllum & Moderate/High & $\begin{array}{l}\mathrm{H} \text { i g h / } \\
\text { moderate }\end{array}$ & $\begin{array}{l}\text { Mixed facies } \\
\text { Olistolith }\end{array}$ \\
\hline Cerro Cabello & RCA5 & & $\begin{array}{l}\text { Wackestone, } \\
\text { Packstone }\end{array}$ & Axophyllum, Lithostrotion & Low & Moderate & Olistolith \\
\hline
\end{tabular}


those of the Sierra Boyera Block. The dominant facies are bioclastic wackestones/packstones and ooidal grainstones (Cózar \& Rodríguez, 1999d; Cózar et al., 2007; Rodríguez $\&$ Said, 2009), such as in most olistoliths, but the abundance and diversity of corals is similar to that in Antolín and El Cañal. They represent mainly shallow platforms and ooidal shoals.

\subsection{Palaeogeography}

The studied outcrops are located in two different tectonostratigraphic units that are separated by strike-slip faults (Wagner, 1999; Simancas et al., 2001), which produced relative movement that could reach more than $100 \mathrm{~km}$ along strike. Consequently, the current position of the different outcrops in the Guadiato Area is very different from that when Viséan sedimentation occurred. The analysis of the coral assemblages allows the identification of some trends that may help to identify the palaeogeographic relationships between the different outcrops.

The outcrops can be divided in three main groups and six sub-groups (Table 1, dark grey). The Sierra del Castillo Unit constitutes the first group of outcrops. It comprises three blocks (or subgroups), the Sierra Boyera Block (Casa de la Calera, Antolín, El Cañal and Sierra Boyera outcrops, SBB), the Couce Block (Couce outcrop) and Sierra del Castillo Block (Cantera Castillo, El Collado, Navacastillo, Sierra de la Estrella 1 and Sierra de la Estrella 2 outcrops, SCB). The olistoliths in San AntonioLa Juliana Unit constitute the second group that are divided in two sub-groups, the Northern subgroup (Castillo Belmez, Sierra Palacios, El Burjadillo and La Juliana outcrops, NOL) and the Southern subgroup (La Adelfilla and Cerro Cabello outcrops, SOL). The outcrops located at the North-west (NOW), Peñarroya, Fuenteobejuna and El Casar (Table 1, light-grey) are located theoretically within the San Antonio-La Juliana Unit and they could be olistoliths, but they are located between major faults and show assemblages and facies that do not coincide with the olistoliths located to the south-east.

With regard to the coral assemblages, some species are typical from deep-water facies with high input of siliciclastics. Their distribution is related to the environment, and has no biogeographic significance (Claviphyllum sp., Cryptophyllum sp., Cyathaxonia cornu, Cyathaxonia rushiana, Rotiphyllum costatum, Rotiphyllum rushianum, Rylstonia benecompacta, Sochkineophyllum? sp., Ufimia bradbournense and Zaphrentites delanouei). In the Guadiato Area they occur when middle or distal platforms are preserved (Couce and Sierra de la Estrella 1). Some other species are widespread in the western Palaeotethys and occur in all units and in most outcrops (Axophyllum pseudokirsopianum, Axophyllum kirsopianum, Clisiophyllum garwoodi, Lithostrotion decipiens, Lithostrotion vorticale, Multithecopora sp. A, Palaeosmilia murchisoni, Siphonodendron martini, Siphonodendron pauciradiale, Siphonodendron sociale). They should be discarded from the analysis, but at least two of these species (Lithostrotion vorticale and Siphonodendron sociale) are absent from the NOW. It means that a certain degree of isolation could affect those outcrops. In the same way, several species occur only in the NOW (Axophyllum spiralum, Axophyllum tazoultense, Diphyphyllum gracile, Roemeripora sp.). Some other species are shared only with the outcrops from the SBB (Amgdalophylloides anticuum, Axophyllum pseudokirsopianum, Morenaphyllum antolinense, Multithecopora sp. B). It indicates a close relationship between those outcrops. It would imply that either the movement of the strike-slip faults was not as important as previously proposed or (more probably) the NOW, limited by faults and surrounded by Cenozoic sediments, are not related with the San Antonio-La Juliana Unit, but with the SBB (Sierra del Castillo Unit). On the other hand, two species (Axophyllum kirsopianum and Gangamophyllum gorskyi) occur only in the NOW and in the olistoliths (NOL and SOL), indicating a closer relationship of the olistoliths with the northern outcrops from Sierra del Castillo Unit than with the southern outcrops of the same unit, that are today more closely located. In addition to the widespread species, no species are in common between the olistoliths and the SCB. The only two exceptions to this fact are Siphonodendron kleffense and Syringopora sp. B, that occur in the southern olistolith of Adelfilla and in the Sierra Boyera Block, indicating a closer relationship of the southern part of the San Antonio-La Juliana Unit, with the northern part of the Sierra del Castillo Unit. It would imply that the strike-slip fault between those units displaced relatively those units more than $50 \mathrm{~km}$ and possibly more than $100 \mathrm{~km}$. When the localities from the San AntonioLa Juliana Unit are displaced to the north-west, the table with the coral occurrences shows a completely consistent distribution (Table 3).

\subsection{Biostratigraphy}

The coral biostratigraphy from the Guadiato Area was discussed and compared with that from Ireland by Rodríguez \& Somerville (2007). Some additional material from El Casar, Fuenteobejuna, Peñarroya, El Cañal, etc. has been studied since then, but no main changes in the biostratigraphy from the upper Viséan from the Guadiato Area can be added here. We identify five biozones. Taking the corals biozones proposed by Mitchell (1989) for Britain and those proposed by Poty et al. (2006) as valid references, the zones 1 and 2 would be equivalent to the zone F in Britain and the zone RC6 in Belgium; the zone 3 would be equivalent to the zone RC7 in Belgium and the 
Table 3. Distribution of taxa in the Guadiato Area outcrops ordered after tectonic rearrangement (possible original position). Note that the random distribution in Table 1 of species with $\mathrm{X}$ in bold become coherent in Table 3 . Abbreviations same as in Table 1.

\begin{tabular}{|c|c|c|c|c|c|c|c|c|c|c|c|c|c|c|c|c|c|c|c|}
\hline \multirow[b]{2}{*}{ Taxa/Sections } & \multicolumn{4}{|c|}{ NOL } & \multicolumn{2}{|c|}{ SOL } & \multicolumn{3}{|c|}{ NOW } & \multicolumn{4}{|c|}{ SBB } & \multicolumn{2}{|l|}{$\mathrm{C}$} & \multicolumn{3}{|c|}{ SCB } & \multirow[b]{2}{*}{ 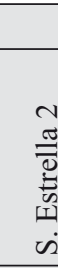 } \\
\hline & 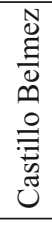 & 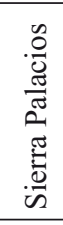 & 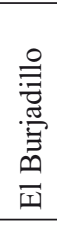 & 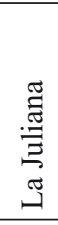 & 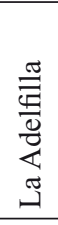 & $\begin{array}{l}\stackrel{0}{\overline{0}} \\
\text { है } \\
0 \\
0 \\
0 \\
0 \\
0\end{array}$ & 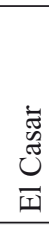 & 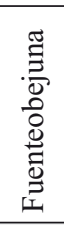 & 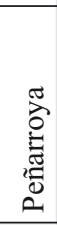 & 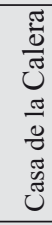 & $\frac{\Xi}{\stackrel{\Xi}{0}}$ & 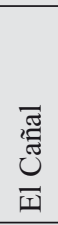 & 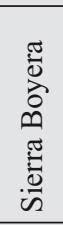 & $\begin{array}{l}\ddot{0} \\
\delta \\
\tilde{\Xi} \\
\text { III }\end{array}$ & 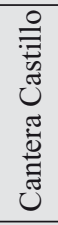 & $\begin{array}{l}\frac{0}{0} \\
\frac{\pi}{0} \\
0 \\
\frac{0}{1}\end{array}$ & 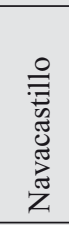 & 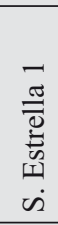 & \\
\hline Amplexocarinia sp. & & & & & & & $\mathrm{x}$ & & $\mathrm{x}$ & & & $\mathrm{x}$ & & & & & & & \\
\hline Amplexus sp. & & & & & & & & & & & & $\mathrm{x}$ & & & & & & & \\
\hline Amygdalophylloides anticuum & & & & & & & $\mathrm{x}$ & $\mathrm{x}$ & $\mathrm{x}$ & $\mathrm{x}$ & & $\mathrm{x}$ & & & & & & & \\
\hline $\begin{array}{l}\text { Amygdalophyllum aff. nexile } \\
\text { Arachnolasma sinense }\end{array}$ & & & & & & & & & & & $\mathrm{x}$ & $\begin{array}{l}\mathrm{x} \\
\mathbf{x}\end{array}$ & & & & $\mathbf{x}$ & & & \\
\hline Auloclisia sp. & & & & & & & & & & & & & & & $\mathrm{x}$ & $\mathrm{x}$ & & $\mathrm{x}$ & \\
\hline Aulokoninckophyllum carinatum & & & & & & & & & & & & & & & & & & $\mathrm{x}$ & \\
\hline Aulophyllum fungites & & & & & & & & & & & & & & & $\mathrm{x}$ & & & & \\
\hline Axoclisia cuspiforma & & & & & & & & & & & $\mathrm{x}$ & & & & $\mathrm{x}$ & & & & \\
\hline Axophyllum cozari & & & & & & & & & & & $\mathrm{x}$ & & & & & & & & \\
\hline Axophyllum densum & & & & & & & & & $\mathbf{x}$ & & & $\mathbf{x}$ & & & $\mathbf{x}$ & $\mathbf{x}$ & & & \\
\hline Axophyllum kirsopianum & $\mathbf{x}$ & $\mathbf{x}$ & & $\mathbf{x}$ & $\mathbf{x}$ & $\mathbf{x}$ & $\mathbf{x}$ & $\mathbf{x}$ & $\mathbf{x}$ & & & & & & & & & & \\
\hline Axophyllum mendipense & & & & & & & & & & & $\mathbf{x}$ & & & $\mathbf{x}$ & & $\mathbf{x}$ & & & \\
\hline Axophyllum pseudokirsopianum & & & & & $\mathbf{x}$ & & & $\mathbf{x}$ & $\mathbf{x}$ & $\mathbf{x}$ & $\mathbf{x}$ & $\mathbf{x}$ & & & & & & & \\
\hline Axophyllum spiralum & & & & & & & $\mathrm{X}$ & $\mathrm{x}$ & $\mathrm{x}$ & & & & & & & & & & \\
\hline Axophyllum tazoultense & & & & & & & $\mathrm{x}$ & & & & & & & & & & & & \\
\hline Axophyllum vaughani & & & & & & & $\mathrm{x}$ & & $\mathrm{x}$ & & & & & & & $\mathrm{x}$ & & & \\
\hline Caninia sp. & & & & & & & & & & & & & & & & $\mathrm{x}$ & & & \\
\hline Caninophyllum becharense & & & & & & & & & & & $\mathrm{x}$ & & & & & & & & \\
\hline Cladochonus (TAB) & & & & & & & & & & & & & & & & $\mathrm{x}$ & & & \\
\hline Claviphyllum sp. & & & & & & & & & & & & & & & & & & $\mathrm{x}$ & \\
\hline Clisiophyllum benziregense & & & & & & & & & & & & & & & & $\mathrm{x}$ & & & \\
\hline Clisiophyllum garwoodi & $\mathrm{x}$ & & $\mathrm{x}$ & & $\mathrm{x}$ & & & & $\mathrm{x}$ & $\mathrm{x}$ & & $\mathrm{x}$ & $\mathrm{x}$ & & $\mathrm{x}$ & $\mathrm{x}$ & & & \\
\hline Cryptophyllum sp. & & & & & & & & & & & & & & $\mathrm{x}$ & & & & $\mathrm{x}$ & \\
\hline Cyathaxonia cornu & & & & & & & & & & & & & & $\mathrm{x}$ & & & & $\mathrm{x}$ & \\
\hline Cyathaxonia rushiana & & & & & & & & & & & & & & $\mathrm{x}$ & & & & $\mathrm{x}$ & \\
\hline Dibunophyllum bipartitum & & & & & & & & & & & & & & & & $\mathrm{x}$ & $\mathrm{x}$ & $\mathrm{x}$ & \\
\hline Diphyphyllum furcatum & & & & & & & & & & & & $\mathrm{x}$ & & & & & & & \\
\hline Diphyphyllum gracile & & & & & & & & & $\mathrm{x}$ & & & & & & & & & & \\
\hline Espielia columellata & & & & & & & & & & & & & & & & $\mathrm{x}$ & & & \\
\hline Gangamophyllum gorskyi & & $\mathbf{x}$ & & & $\mathbf{x}$ & $\mathbf{x}$ & & $\mathbf{x}$ & $\mathbf{x}$ & & & & & & & & & & \\
\hline Gangamophyllum mosquense & & & & & & & $\mathrm{x}$ & & & & & & & & & $\mathrm{x}$ & & & \\
\hline Haplolasma lamelliferum & & & & & & & & & & & & & & & & $\mathrm{x}$ & & & \\
\hline Heterophyllia ornata (HETERO) & & & & & & & & & & & $\mathbf{x}$ & $\mathbf{x}$ & & & & $\mathbf{x}$ & & & \\
\hline Hexaphyllia marginata (HETERO) & & & & & & & & & & & $\mathbf{x}$ & & & & $\mathbf{x}$ & $\mathbf{x}$ & & & \\
\hline Koninckophyllum interruptum & & & & & & & & & & & & $\mathrm{x}$ & & & $\mathrm{x}$ & $\mathrm{x}$ & & & \\
\hline Lithostrotion araneum & & & & & & & & & & & $\mathrm{x}$ & $\mathrm{x}$ & & & & & & & \\
\hline Lithostrotion decipiens & & & & $\mathrm{x}$ & & & & $\mathrm{x}$ & & & & & $\mathrm{x}$ & & & & & & $\mathrm{x}$ \\
\hline Lithostrotion vorticale & & & $\mathrm{x}$ & $\mathrm{x}$ & $\mathrm{x}$ & $\mathrm{x}$ & & & & & $\mathrm{x}$ & $\mathrm{x}$ & & & $\mathrm{x}$ & $\mathrm{x}$ & $\mathrm{x}$ & $\mathrm{x}$ & $\mathrm{x}$ \\
\hline Morenaphyllum antolinense & & & & & & & & & & & $\mathrm{x}$ & & & & & & & & \\
\hline Morenaphyllum boyerense & & & & & & & & & & & $\mathrm{x}$ & & & & & & & & \\
\hline Morenaphyllum sp. & & & & & & & & $\mathrm{x}$ & & & & & & & & & & & \\
\hline Multithecopora sp. A (TAB) & & & & & & & & $\mathbf{x}$ & & & $\mathbf{x}$ & $\mathbf{x}$ & & & & $\mathbf{x}$ & & $\mathbf{x}$ & \\
\hline Multithecopora sp. B (TAB) & & & & & & & & $\mathrm{x}$ & & & $\mathrm{x}$ & $\mathrm{x}$ & & & & & & & \\
\hline Multithecopora sp. C (TAB) & & & & & & & & & & & & & & & & $\mathrm{x}$ & & & \\
\hline Palaeosmilia murchisoni & $\mathrm{X}$ & & & $\mathrm{x}$ & $\mathrm{X}$ & $\mathrm{x}$ & $\mathrm{x}$ & $\mathrm{x}$ & $\mathrm{x}$ & $\mathrm{X}$ & & $\mathrm{x}$ & $\mathrm{x}$ & & $\mathrm{x}$ & $\mathrm{x}$ & $\mathrm{x}$ & $\mathrm{x}$ & \\
\hline Palastraea regia & & & & & & & & & & & & $\mathrm{x}$ & & & & $\mathrm{x}$ & & & \\
\hline Pseudozaphrentoides sp. & & & & & & & & & & & & & & & $\mathrm{x}$ & $\mathrm{x}$ & & & \\
\hline Roemeripora sp. (TAB) & & & & & & & & $\mathrm{x}$ & & & & & & & & & & & \\
\hline Rotiphyllum costatum & & & & & & & & & & & & & & & & & & $\mathrm{x}$ & \\
\hline Rotiphyllum rushianum & & & & & & & & & & & & & & $\mathrm{x}$ & & & & $\mathrm{x}$ & \\
\hline
\end{tabular}




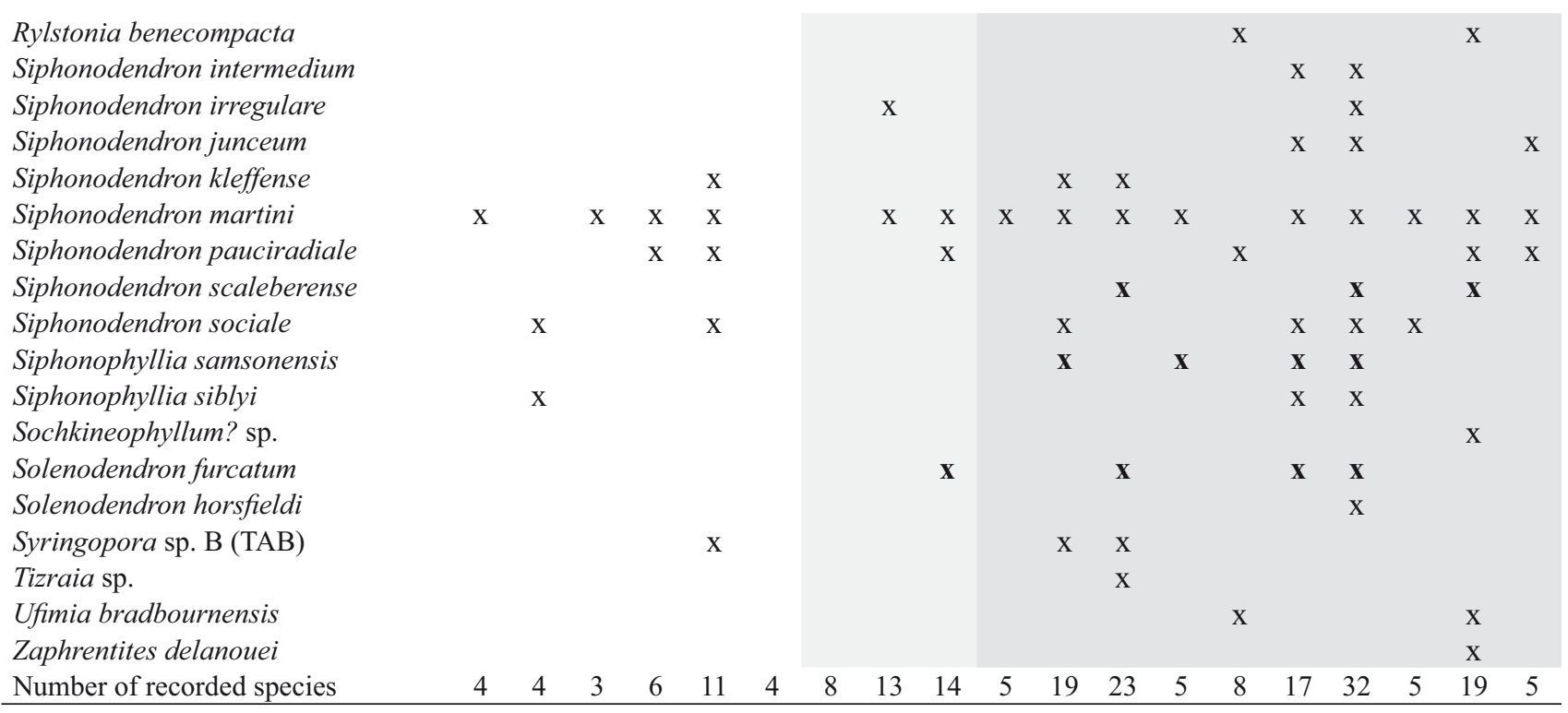

zone $\mathrm{G}$ in Britain; the zones 4 and 5 would be equivalent to the zones H and I in Britain and the zone RC8 in Belgium.

\section{RESULTS AND CONCLUSIONS}

69 species belonging to Rugosa, Tabulata and Heterocorallia have been recorded in the Viséan from the Guadiato Area up to date. The degree of diversity is not very high but it matches with the records in other regions of the western Palaeotethys. High abundance is restricted to some biostromes (El Collado) and concentration in debris (Antolín).

The level of endemism is low, with only six species unknown in other regions. Two genera first described in the Guadiato Area have been subsequently recorded in North Africa and Turkey respectively.

The Viséan corals from the Guadiato Area lived in diverse environments, from shallow platforms, shoals and reefs to middle and outer platforms. In some cases, the corals have been recorded from debris that are the result of destruction of non-preserved shelfs.

The palaeogeographical distribution of the assemblages in the studied outcrops shows some anomalies, which become reduced when considering the relative movement of the strike-slip faults that separate the Sierra del Castillo and the San Antonio-La Juliana units, substantiating the supposed movement of many tens of kilometres during the Variscan Orogeny.

The new data corroborate the biostratigraphical distribution expressed by Rodríguez \& Somerville (2007). Five zones comprising only part of the Upper Viséan are discernible, which are equivalent to the zones RC6-RC8 in Belgium and the zones F-I in Britain.

\section{ACKNOWLEDGEMENTS}

Financial support through the Spanish Ministerio de Economía y Competitividad (research project CGL201230922BTE) and Complutense University Research Group (910231) is gratefully acknowledged. This research is a contribution to the IGCP Project 596, Climate change and biodiversity patterns in the Mid-Palaeozoic. This paper has benefited from the constructive comments of Dr. J. Denayer and Prof. X.D. Wang.

\section{REFERENCES}

Apalategui, O., Borrero, J.E. \& Higueras, P. 1985. División en grupos de rocas en Ossa-Morena oriental. In: $5^{a}$ Reunión del Grupo de Ossa-Morena. Temas Geológicos y Mineros, Instituto Geológico y Minero de España, 7, 73-80.

Aretz, M. 2002. Habitatanalyse und Riffbildspotential kolonialer rugoser Korallen im Unterkarbon (Mississippium) von Westeuropa. Kölner Forum für Geologie und Paläontologie, 10, 1-155.

Aretz, M. 2010. Habitats of colonial rugose corals: the Mississippian (Carboniferous) of Western Europe as example for a general classification. Lethaia, 43, 558-572; doi:10.1111/j.1502-3931.2010.00218.

Aretz, M. 2011. Corals from the Carboniferous of the central Sahara (Algeria): the collection of "Marie Legrand-Blain". Geodiversitas, 33 (4), 581-624; doi:10.5252/g2011n4a3.

Aretz, M. \& Herbig, H.G. 2010. Corals from the Viséan of the central and southern part of Azrou-Khénifra Basin (Carboniferous, Central Moroccan Meseta). In: Fossil corals, archaeocyaths and sponges. Proceedings of the $10^{\text {th }}$ International Symposium on Fossil Cnidaria and Porifera, St Petersburg. Palaeoworld, 19 (3-4), 295-304; doi:10.1016/j.palwor.2010.08.003. 
Bykova, M. S. 1966. Niznekamennougolnye korally Vostochnogo Kazakstana. Trudy Instituta Geologicheski Nauk Kazakstan. Institut Geologicheski Kazakskoi SSR: 1-214.

Carruthers, R.G. 1909. A revision of some Carboniferous corals. Geological Magazine, 5, 20-171.

Carruthers, R.G. 1910. On the evolution of Zaphrentis delanouei. Quarterly Journal of the Geological Society, 66, 523-538.

Carruthers, R.G. 1919. A remarkable Carboniferous coral. Geological Magazine, 16, 436-441.

Chacón, J., Delgado-Quesada, M.Y. \& Garrote, A. 1974. Sobre la existencia de dos diferentes dominios de metamorfismo regional en la banda Elvas-Badajoz-Córdoba (Macizo Hespérico Meridional). Boletín Geológico y Minero, 85 (VI), 713-717.

Chapman, E.J. 1893. On the corals and coralliform types of Paleozoic strata. Transactions of the Royal Society of Canada, 10 (4), 39-48.

Chi, Y.S. 1935. Aditional fossil corals from the Weiningian limestones (SW China). Palaeontologica Sinica, 12 (6), 1-38.

Coronado, I. \& Rodríguez, S. 2014. Carboniferous auloporids from the Iberian Peninsula: palaeocology, diversity, and spatio-temporal distribution. Journal of Iberian Geology, 40 (1), 61-85; doi:10.5209/rev_JIGE.2014.v40.n1.44088.

Cossey, P.J. 1997. Hexaphyllia: a spiny heterocoral from Lower Carboniferous reef limestones in Derbyshire, England. Palaeontology, 40 (4), 1031-1059.

Cotton, G. 1984. The revised Rugose coral genera. Cotton, Kiddermister, 1-283.

Cózar, P. \& Rodríguez, S. 1999a. Propuesta de nueva nomenclatura para las unidades del Carbonífero Inferior del sector Norte del Área del Guadiato (Córdoba). Boletín Geológico y Minero, 110 (3), 237-254.

Cózar, P. \& Rodríguez, S. 1999b. Evolución sedimentaria del Carbonífero Inferior del Área del Guadiato. Boletín Geológico y Minero, 110 (6), 663-680.

Cózar, P. \& Rodríguez, S. 1999c. Descripción e interpretación de los afloramientos del Carbonífero Inferior en las proximidades de Peñarroya-Pueblonuevo (Córdoba, España). Coloquios de Paleontología, 50, 161-200.

Cózar, P. \& Rodríguez, S. 1999d. Sedimentología y bioestratigrafía del Viseense del área de Sierra Palacios, Valle del Guadiato (Córdoba, España). Boletín de la Real Sociedad Española de Historia Natural, 95 (1-4), 47-65.

Cózar, P. \& Rodríguez, S. 2000. Caracterización estratigráfica y sedimentológica del Viseense superior de Sierra Boyera (Área del Guadiato, SO de España). Revista de la Sociedad Geológica de España, 13 (1), 91-103.

Cózar, P. \& Rodríguez, S. 2001. Precisiones sedimentológicas y estratigráficas en la Unidad del Fresnedoso, Área del Guadiato (Mississippiense, SO de España). Boletín de la Real Sociedad Española de Historia Natural (Sección Geológica), 96 (3-4), 203-214.

Cózar, P., Somerville, I.D., Rodríguez, S. \& Medina-Varea, P. 2007. New genera of late Viséan metaspondil dasycladales from the Fuenteobejuna section (Mississippian of the Guadiato Valley, southwestern Spain). Neues
Jahrbuch für Geologie und Paläontologie, 246, 97-109; doi:10.1127/0077-7749/2007/0246-0097.

Cózar, P., Rodríguez-Martínez, M., Falces, S., Mas, R. \& Rodríguez, S. 2003. Stratigraphic setting in the development of microbial mud mounds of the Lower Carboniferous of Guadiato Area (SW Spain). In: PermoCarboniferous carbonate platforms and reefs (eds. Ahr, W.M, Harris, P.M, Morgan, W.A. \& Somerville, I.D.). Society of Economic Palaeontologists and Mineralogists, Special Publication \& American Association of Petroleum Geologists, Memoir, 78 \& 83, 57-67.

Dana, J.D. 1846. Genera of fossil corals of the family Cyathophyllidae. American Journal of Science, 1, 181-184.

Delgado-Quesada, M., Liñán, E., Pacual, E. \& PérezLorente, F. 1977. Criterios para la diferenciación de dominios en Sierra Morena central. Studia Geologica, 12, 75-90.

Denayer, J. 2012. Corals of the Upper Viséan microbialsponge-bryozoan-coral bioherm and related strata of Kongul Yayla (Taurides, South Turkey). Geologica Belgica, 15 (4), 317-328.

Denayer, J., Poty, E. \& Aretz, M. 2011. Uppermost Devonian and Dinantian rugose corals from Southern Belgium and surrounding areas. In: Field Guides $11^{\text {th }}$ International Symposium on Fossil Cnidaria and Porifera, Liège 2011 (eds. Aretz, M. \& Poty, E.). Kolner Forum von Geologie und Paleontologie, 20, 151-201.

Dobrolyubova, T.A. 1937. Odinochnye korally mjachkovskogo i podolskogo gorizontov srednego karbona Podmoskovnogo basseina. Trudy Paleontologicheski Institut, 6 (3), 1-92.

Dobrolyubova, T.A. 1952. Koralli roda Gangamophyllum iz nizhnego Karbona podmoskovnoi kotlovinii. Trudy Paleontologicheski Institut, 40, 51-69.

Dobrolyubova, T.A. \& Kabakovich, N.V. 1948. Nekotorie predstabiteli Rugosa srednego i verjnego Karbona podmoskovnogo basseina. Trudy Paleontologicheski Institut, 14 (2), 1-34.

Dun, W.S. \& Benson, W.N. 1920. The Geology and petrology of the Great Serpentine Belt of N.S. Wales pt. IX: the geology, paleontology and petrography of the Currrabubula district, with notes on adjacent regions. Proceedings of the Linnean Society of New South Wales, 45 (3), 337-363.

Dybowski, W.N. 1873. Beschreibung einiger neuen oder wenig bekennten Arten der Zoantharia rugosa aus der Kohlenformation Russlands. Zapadnogo Imperialnogo Minerali ob-va, 8, 102-116.

Ehrenberg, C.G. 1834. Beitrage zur ohysiologischen Kenntniss der Korallentiere im allgemein und besonders des rothen Meeres, nebst einem Versuche zur physiologischen Systematik derselben. Physiologische abhandlungen der könige Akademie von Wissenschaften Berlin, 1832, 225-380.

Fedorowski, J. 1968. Upper Visean Tetracoralla from some borings in the Lublin Coal mesures (Poland). Acta Palaeontologica Polonica, 13 (2), 203-217.

Fedorowski, J. 1971. Aulophyllidae (Tetracoralla from the Upper Visean of Sudetes and Holy Cross Mountains). Palaeontologica Polonica, 24, 1-137. 
Fedorowski, J. 1975. Lower Carboniferous tetracoral fauna in Poland. Drevnie Cnidaria, 2, 170-178.

Fedorowski, J. 2009. On Pentamplexus Schindewolf, 1940 (Anthozoa, Rugosa) and its possible relatives and analogues. Palaeontology, 52 (2), 197-322; doi:10.1111 /j.1475-4983.2008.00844.

Fedorowski, J. 2010. Remarks on rugose coral taxonomy. Palaeoworld, 19, 242-248; doi:10.1016/j. palwor.2010.09.005.

Fleming, J. 1823. Gleanings of natural history, gathered on the coast of Scotland during a voyage in 1821. Edinburgh New Philosophical Journal, 8, 294-303.

Fleming, J. 1828. A history of British animals. Beel and Bradfute, Edinburgh, 1-565.

Fomichev, V.D. 1953. Koralli Rugosa i stratigrafia Sredne i Verkhnekamennougolnikh i Permskikh oblochenii Donetzkogo Basseina. Trudy VNIGRI, 1-622.

Fromentel, E. de 1861. Introduction à l'etude des polypiers fossils. Savy Editeur, Paris, 1-357.

Gabaldón, V., Garrote, A. \& Quesada, C. 1985a. E1 Carbonífero inferior del norte de la zona de Ossa-Morena (SO de España). Compte Rendu X Congrès International de Stratigraphie et de Géologie du Carbonifère, Madrid 1983, 3, 173-186.

Gabaldón, V. Garrote, A. \& Quesada, C. 1985b. Geología del Carbonífero Inferior del norte de Ossa-Morena. Introducción a la excursión $5^{\mathrm{a}}$ Reunión. In: V Reunión del Grupo de Ossa-Morena, Instituto Geológico y Minero de España, Temas Geológico y Mineros, 7, 101- 105.

Gervais, P. 1840. Astrées, Astrea. In: Dictionnaire des Sciences naturelles, supplement 1, 481-487. Paris.

Goldfuss, A. 1826. Petrefacta Germaniae, 1, 1-76. Dusseldorf.

Golonka, J. 2012. Plate-tectonic maps of the Phanerozoic. Special Publications of SEPM, 72, 21-75.

Gorsky, I.I. 1938. Kamennougonie koralli Novoi Zemli. Trudy Arktiya Instituta, 93, 1-221.

Grabau, A.W. 1922. Palaeozoic corals of China. Part 1. Tetraseptata. Palaeontologica Sinica, Series B, 2, 1-76.

Grabau, A.W. 1928. Palaeozoic corals of China. Part I. Tetraseptata. Palaeontologica Sinica, 2, 1-175.

Grabau, A.W. 1930. Corals of the Upper Silurian Spirifer Tingi beds of Kweichow. Palaeontologica Sinica, 9 (3), 223-247.

Groot, G.E. de 1963. Rugose corals from the Carboniferous of Northern Palencia (Spain). Leidse Geologische Mededelingen, 29, 1-123.

Hill, D. 1938-1941. A monograph on the Carboniferous rugose corals of Scotland. Palaeontological Society of London Monograph, Pt. 1 (1-78), Pt. 2 (79-114), Pt. 3 (115-204).

Hill, D. 1956. Rugosa. In: Treatise on Invertebrate Palaeontology, F, F233-F327 (ed. Moore, R.C.). Lawrence, Kansas.

Hill, D. 1981. Rugosa and Tabulata. In: Treatise on Invertebrate Paleontology. Part F (Supplement 1) (ed. Teichert, C.). Geological Society of America and University of Kansas Press, Boulder Colorado and Lawrence, Kansas (2 vols).
Hudson, R.G. 1941. On the Carboniferous corals: Zaphrentis carruthersi sp. nov. from the Mirk Fell beds and its relation to the $Z$. delanouei species group. Proceedings of the Yorkshire Geological Society, 24, 290-311; doi:10.1144/pygs.24.4.290.

Hudson, R.G. 1942. On the Lower Carboniferous corals: Rylstonia benecompacta var. brevisepta, var. nov. Proceedings of the Yorkshire Geological Society, 24 (5), 373-382; doi:10.1144/pygs.24.5.373.

Hudson, R.G. 1944. On the Lower Carboniferous corals: Zaphrentites crassus and Z. tenuis sp. nov. Annals and Magazine of Natural History, 11, 145-154; doi:10.1080/00222934408527416.

Hudson, R.G. \& Platt, M.I. 1927. On the Lower Carboniferous corals: The development of Rylstonia benecompacta, gen. and sp. nov. Annals and Magazine of Natural History, 19 (9), 39-48; doi:10.1080/00222932708633571.

Iljina, T.G. 1970. Nekotorie novie permiskie rugozi YugoVostochnogo Pamira. Novie Vidy Paleozoiskij mshanok $i$ korallov Nauka, 146-151.

Khoa, N.D. 1977. Carboniferous rugosa and heterocorallia from boreholes in the Lublin region (Poland). Acta Palaeontologica Polonica, 22, 301-404.

Koker, E.M. 1924. Anthozoa uit het perm van het eiland Timor, I, Zaphrentidae, Plerophyllidae, Cystiphyllidae, Amphiastraeidae. Jaarbuch Mijnwezen Nederland OostIndie, 51, 1-50.

Kraicz, I. 1934. Die systematische Stellung von Roemeria bohemica Barrande. Lotos, 82, 38-46.

Lewis, H.P. 1927. On Auloclisia, a new coral genus from the Carboniferous Limestone. Proceedings of the Yorkshire Geological Society, 21, 29-46; doi:10.1144/pygs.21.1.29.

Lewis, H.P. 1929. On the Avonian coral Caninophyllum gen. nov. and C. archiaci (Edwards \& Haime). Annals and Magazine of Natural History, Series 10, 3, 456-468; doi:10.1080/00222932908672999.

Lonsdale, W. 1845. Description of some characteristic Palaeozoic corals of Russia. Géologie de la Russie d'Europe et des Montagnes de l'Oural, 1, 291-364.

McCoy, F. 1844. A synopsis of the characters of the Carboniferous limestone fossils of Ireland. University Press, Dublin, 1-207.

McCoy, F. 1847. On the fossil botany and zoology of the rocks associated with the coal of Australia. Annals and Magazine of Natural History, Series 2, 1-20, 145-157, 226-236, 298-312.

McCoy, F. 1849. On some new genera and species of Palaeozoic Corals and Foraminifera. Annals and Magazine of Natural History, Series 2, 3, 1-20, 119-136.

McCoy, F. 1851. A description of some new Mountain Limestone fossils. Annals and Magazine of Natural History, Series 2, 167-175.

Michelin, J.L. 1847. Iconographie zoophytologique, description par localités et terrains des polypiers fossiles de France et pays environments. P, 1-348.

Milne-Edwards, H. \& Haime, J. 1848. Recherches sur les polypiers, Premier général. Annales des Sciences Naturelles, 9, 37-89. 
Milne-Edwards, H. \& Haime, J. 1850-1855. A Monograph of the British fossil corals. 1850 (1-71), 1852 (147-210), 1853 (211-244), 1855 (245-299). Palaeontographical Society, London.

Milne-Edwards, H. \& Haime, J. 1851-1855. Monographie des polypiers fossils des terrains palaeozoiques, précédée d'un tableau general de la classification des Polypes. Archives du Museum d'Histoire Naturelle de Paris, Paris, 1-502.

Mitchell, M., 1989. Biostratigraphy of Viséan (Dinantian) rugose coral faunas from Britain. Proceedings of the Yorkshire Geological Society, 47, 233-247; doi:10.1144/ pygs.47.3.233.

Moore, R.C. \& Jeffords, R.M. 1941. New Permian corals from Kansas, Oklahoma and Texas. Kansas State Geological Survey Bulletin, 38, 65-120.

Nicholson, H.A. 1889. Descriptions of new species of rugose corals from the Carboniferous rocks of Scotland. Proceedings of the Royal Philosophical Society of Glasgow, 10 (1), 119-132.

Nudds, J.R. 1980. An illustrated key to the British lithostrotionid corals. Acta Palaeontologica Polonica, 25, 385-394.

Nudds, J.R. \& Somerville, I.D. 1987. Two new species of Siphonodendron (Rugosa) from the Viséan of the British Isles. Proceedings of the Yorkshire Geological Society, 46 (4), 293-300; doi:10.1144/pygs.46.4.293.

Orbigny, A. d' 1852. Prodrome de Paléontologie, Stratigraphique universelle des animaux mollusques \& rayonnés faisant suitre au cours élémentaire de paléontologie et de géologie stratigraphique, 3. Victor Masson, Paris.

Parkinson, J. 1808. Organic remains of a former world. 2, 1-286. London

Phillips, J. 1836. Illustrations of the geology of Yorkshire. 8, 1-253. London

Pocta, P. 1902. Anthozoaires et Alcyonaires. In: Système Silurien du Centre de la Bohême. Partie I. Recherches Paléontologiques (ed. Barrande, J.). VIII.2.-I-VIII, 1-347, Musée Bohême, Prague.

Poty, E. 1981. Recherches sur les Tétracoralliaires et les Hétérocoralliaires du Viséen de la Belgique. Mededelingen Rijks Geologische Dienst, 35-1, 1-161.

Poty, E. 1984. An evolutionary pattern for the Western European Lithostrotionidae. Palaeontographica Americana, 54, 465-469.

Poty, E. \& Boland, K. 1994. Revision des tetracoralliaires caninomorphes de l'Hastarien (Tournaisien) belge. Annales de la Société Géologique de Belgique, 117 (1), 201-225.

Poty, E., Devuyst, F.X., \& Hance, L. 2006. Upper Devonian and Mississippian foraminiferal and rugose coral zonation of Belgium and northern France: a tool for Eurasian correlations. Geological Magazine, 143 (6), 829-857; doi:10.1017/S0016756806002457.

Rodríguez, S. 1984. Corales rugosos del Carbonífero del Este de Asturias. PhD Thesis, Universidad Complutense de Madrid, 109 (84), 1-528.
Rodríguez, S. 2004. Taphonomic alterations in upper Viséan dissepimented rugose corals from the Sierra del Castillo unit (Carboniferous, Córdoba, Spain). Palaeogeography, Palaeoclimatology, Palaeoecology, 214, 135-153; doi:10.1016/j.palaeo.2004.07.026.

Rodríguez, S. \& Falces, S. 1996. Los corales rugosos del Carbonífero de Ossa-Morena: Estado actual de los conocimientos. Revista Española de Paleontología, 97102.

Rodríguez, S. \& Hernando, J.M. 2005. Description of Espielia columellata gen. and sp. nov. (Rugosa) from the Sierra del Castillo Unit (upper Viséan, Córdoba, SW Spain). Géobios, 38, 553-561; doi:10.1016/j.geobios.2003.12.004.

Rodríguez, S. \& Rodríguez-Curt, L. 2002. Reconstrucción de una plataforma carbonatada Viseense no preservada en el área del Guadiato (Córdoba, SO de España). Geogaceta 32, 283-286.

Rodríguez, S. \& Said, I. 2009. Descripción de los corales rugosos del Viseense superior de Peñarroya-Pueblonuevo (Córdoba) y El Casar (Badajoz). Coloquios de Palaeontología, 59, 7-27.

Rodríguez, S. \& Somerville, I.D. 2007. Comparison of rugose corals from the Upper Viséan of SW Spain and Ireland: implications for improved resolutions in the late Mississippian coral biostratigraphy. In: Fossil Corals and Sponges (eds. Hubman, B \& Piller, W.E.). Proceedings of the $9^{\text {th }}$ International Symposium on Fossil Cnidaria and Porifera, Graz, 2003. Austrian Academy of Sciences, Schriftenreihe der Erdwissenschaftlichen Kommissionen, 17, 275-302.

Rodríguez, S. \& Somerville, I.D. 2014. The Axophyllinae from SW Spain: a review. Boletín de la Real Sociedad Española de Historia Natural, Sección Geológica, 108, 81-137.

Rodríguez, S., Rodríguez-Curt, L. \& Hernando, J.M. 2001a. Estudio de los Aulophyllidae (Rugosa) del Viseense superior de la Unidad de la Sierra del Castillo (Córdoba, España). Coloquios de Paleontología, 52, 47-78.

Rodríguez, S., Hernando, J.M. \& Said, I. 2001b. Estudio de los corales con aulos del Viseense (Carbonífero) de la Unidad de la Sierra del Castillo (Área del Guadiato, SO de España). Coloquios de Paleontología, 52, 85-94.

Rodríguez, S., Hernando, J.M. \& Rodríguez-Curt, L. 2002. Estudio de los corales lithostrotiónidos del Viseense (Misisipiense) de la Unidad de la Sierra del Castillo (Córdoba), España. Revista Española de Paleontología, 17, 13-36.

Rodríguez, S., Hernando, J.M. \& Rodríguez-Curt, L. 2004. Estudio de los corales cyathópsidos (Rugosa) del Viseense superior de la Unidad de la Sierra del Castillo (Córdoba, España). Coloquios de Paleontología, 54, 71-84.

Rodríguez, S., Somerville, I.D., Said, I. \& Cózar, P. 2013. Rugose corals from a Carboniferous biostrome in the Tindouf Basin, S. Morocco. Spanish Journal of Palaeontology, 28 (2), 255-284.

Rodríguez, S., Arribas, M.E., Bermúdez-Rochas, D.D., Calvo, A., Cózar, P., Falces, S., Hernando, J.M., Mas, J.R., MorenoEiris, E., Peña, J.A. de la, Perejón, A., Sánchez-Chico, F. \& 
Somerville, I.D. 2007. Stratigraphical and palaeontological synthesis of the Sierra del Castillo succession (late Viséan, Córdoba, SW Spain). In: Proceedings of the XVth International Congress on Carboniferous and Permian Stratigraphy (ed. Wong, T.E.). Royal Netherlands Academy of Arts and Sciences, Amsterdam, 205-216.

Rodríguez-Martínez, M., Cózar, P., Mas, R. \& Rodríguez, S. 2003. Upper Viséan Saccamminopsis-sponge microbial mud mounds, Sierra de la Estrella, Southwestern Spain. In: Permo-Carboniferous carbonate platforms and reefs (eds. Ahr, W.M., Harris, P.M., Morgan, W.A. \& Somerville, I.D.). Society of Economic Palaeontologists and Mineralogists, Special Publication \& American Association of Petroleum Geologists, Memoir, 78 \& 83, 189-200.

Ryder, T.A. 1930. Notes on "Carcinophyllum" Nich. and Thom. with description of two new species. Annals and Magazine of Natural History, 5, 337-351; doi:10.1080/00222933008673144.

Said, I. \& Rodríguez, S. 2007. A new genus of coral (Rugosa) from the Adarouch Area (Brigantian, NE Cetral Morocco). Coloquios de Paleontología, 57, 23-35.

Said, I., Berkhli, M. \& Rodríguez, S. 2007. Preliminary data on the coral distribution in the Viséan from Adarouch Area, Central Messeta (Morocco). Schriftenreihe der Erdwissenschaftlichen Kommissionen, 17, 353-363.

Said, I., Somerville, I.D., Rodríguez, S. \& Cózar, P. 2013. Mississippian corals from the Khenifra Area, central Morocco: variation in assemblages related to changes in facies and paleoecology. Gondwana Research, 23, 367379; doi:10.1016/j.gr.2012.04.008.

Salée, A. 1913. Contribution á l'ètude de polypiers du calcaire carbonifére de la Belgique II. Le groupe des Clisiophyllides. Memoires de l'Institut Géologique de l'Université de Louvain, 1, 179-293.

San José, M.A. de, Herranz, P. \& Pieren, A. 2004. A review of the Ossa-Morena Zone and its limits. Implications for the definition of the Lusitan-Marianic Zone. Journal of Iberian Geology, 30, 7-22.

Sando, W.J. 1976. Revision of the Carboniferous genus Aulina Smith (Coelenterata, Anthozoa). Journal of Research, $U$. S. Geological Survey, 4 (4), 421-435.

Schindewolf, O.H. 1927. Prinzipienfragen der biologischen Systematik. Paläontologische Zeitschrift, 9, 122-169.

Schindewolf, O.H. 1938. Zur Kenntniss der Gattung Zaphrentis (Anthozoa, Tetrakorallia) und er sogennanten Zaphrentiden des Karbons. Jahrbuch der Preussische geologische Landesanstalt, 58, 439-454.

Schindewolf, O.H. 1941. Zur Kenntnis der Heterophylliden, einer eigentümlichen paläozoischen Korallengruppe. Palaeontologische Zeitschrift, 22, 213-306.

Schindewolf, O.H. 1942. Zur Kenntnis der Polycoelien und Plerophyllen. Eine Studie über ihre Beziehungen zu den "Madreporarien". Abhandlungen der Reichsanstalt Bodenforschungen, 204, 5-324.

Semenoff-Tian-Chansky, P. 1974. Recherches sur les Tétracoralliaires du Carbonifére du Sahara Occidental. Éditions du Centre Nationale de la Recherche Scientifique, Ser. 6, Science de la Terre, 30, 1-316.
Semenoff-Tian-Chansky, P. 1985. Corals. In: The Carboniferous of the World, II, Australia, Indian subcontinent, South Africa, South America and North Africa (eds. Wagner, R.H., Winkler-Prins, C.F. \& Granados, L.F.), IUGS Publication 20, 374-381, 431435.

Semenoff-Tian-Chansky, P. \& Nudds, J.R. 1979. Révision de quelques espèces de Lithostrotion des îles Britanniques déscrites par Milne-Edwards \& Haime (Tetracoralliaries carbnifères). Bulletin du Muséum national d'Histoire naturelle du Paris, IV sér., 1 (C-3), 245-283.

Sibly, T.F. 1906. On the Carboniferous Limestone (Avonian) of the Mendip Area (Somerset) with special reference to the palaeontological sequence. Quarterly Journal of the Geological Society, 62, 324-380.

Simancas, J.F., Martínez-Poyatos, D., Expósito, I., Azor, A. \& González-Lodeiro, F. 2001. The structure of a major suture zone in the SW Iberian Massif: the Ossa-Morena/ Central Iberian contact. Tectonophysics, 332, 295-308.

Smith, S. 1925. The genus Aulina. Annals and Magazine of Natural History, 16, 485-496; doi:10.1080/00222932508633337.

Smith, S. \& Yü, C.C, 1943. A revision of the coral genus Aulina Smith and descriptiones of new species from Britain and China. Quarterly Journal of the Geological Society of London, 99 (1-2), 37-61.

Sokolov, B.S. 1947. Novie siringoporidi Taimira. Biologiya Moskovskoe obshetsvo ispitatelei prirodi, 22 (6), 19-28.

Sokolov, B.S. 1950. Jetetidi Karbona Severo-Vostochnoi Ukranii i sopredelnij. Trudy VNIGRI, 27, 3-144.

Sokolov, B.S. 1960. Permskie korali yugo-vostochnoi chasti Omolonskogo masiva (s obshim obzorom plerofilloidnij rugoz). Trudy VNIGRI, 154, 38-77.

Somerville, I.D. \& Rodríguez, S., 2007. Rugose coral associations from the Upper Viséan of Ireland, Britain and SW Spain. In: Fossil Corals and Sponges: Proceedings of the 9th International Symposium on Fossil Cnidaria and Porifera, Graz 2003 (eds. Hubmann, B. \& Piller, W.E.). Austrian Academy of Sciences, Schriftenreihe der Erdwissenschaftlichen Kommissionen, 17, 329-351.

Soshkina, E. 1925. Les coraux du Permien inférieur (étage d'Artinsk) du versant occidental de l'Oural. Bulletin de la Societé de Naturalistes de Moscou, 33 (3), 76-102.

Soshkina, E., Dobrolyubova, T. \& Porfiriev, G. 1941. The Permian rugose corals of the European part of the USSR. In: Paleontology of the USSR, 5 (3), 1-285.

Sowerby, J. 1814. Article XI. Annals of Philosophy, Linnean Society of London, 4, 1-448.

Spassky, N.I. 1974. Dialekticheskoe edinstuo prostranstuennov remennykh zakonomernostey evolyotsii (na primere chetyrekhluchevgkh korallov). Leningradskogo Gornogo Instituta, 67 (2), 127-135.

Stukenberg, A.A. 1895. Koralli i mshanki kamennougolnij otlodzhenii Urala i Timana. Trudy Geologicheski Komite, 3, 3-178.

Stukenberg, A.A. 1904. Koralli i mshanki nizhnego otdela srednerusskogo kamennougolnogo izvestniaka. Trudy Geologicheski Komite, 14, 3-67. 
Tchudinova, I.I. 1986. Sostav sistema i filogeniya iskopaemij korallov. Otriad siringoporida. Trudy Paleontologicheski Institut, 216, 1-204.

Thomson, J. \& Nicholson, H.A. 1876. Contribution to the study of the chief generic types of the Palaeozoic corals. Annals and Magazine of Natural History, 16 (11), 305309.

Vassiljuk, N.P. 1960. Niznekamennougolnie koralli Donetzkogo basseina. Trudy Instituta Geologichesky Nauk Ukrania, 13, 1-179.

Vassiljuk, N.P. 1964. Korall'y Zon C1vg-C1na Donetskogo Basseyna. Trudy Instituta Geologichesky Nauk Ukrania, 48, 60-103.

Vaughan, A. 1906. Faunal lists and account of the faunal succession and correlation. In: The Carboniferous rocks at Rush (County Dublin) (eds. Matley, C.A. \& Vaughan, A.R.). Quarterly Journal of the Geological Society of London, 62, 295-322.

Vaughan, A. 1908. The Carboniferous rocks at Loughshinny (County Dublin) with an account of the faunal succession and correlation. Quarterly Journal of the Geological Society, 64 (3), 413-474.

Verrill, A.E. 1865. Classification of polyps (Extract condensed from a synopsis of the polypi of the North Pacific Exploring Expedition, under captains Ringgold and Rodgers, U.S.N.). Essex Institute Proceedings, 4, 145-149.
Waagen, W. \& Wentzel, J. 1886. Salt Range fossils. I. Productus-Limestone fossils. Palaeontologica Indica, 1 (5-7), 771-998.

Wagner, R.H. 1999. Peñarroya, a strike-slip controlled basin of early Westphalian age in Southwest Spain. Bulletin of Geosciences, 74 (2), 87-108.

Wagner, R.H. 2004. The Iberian Massif: a Carboniferous assembly. Journal of Iberian Geology, 30, 93-108.

Wang, H.Z. 1950. A revision of the zoantharia rugosa in the light of their minute skeletal structures. Philosophical Transactions of the Royal Society of London, 234, 175246.

Wedekind, R. 1927. Die Zoantharia-Rugose von Gotland (bes. Nordgotland) nebst Bemerkungen zur Biostratigraphie des Gotlandium. Sveriges Geologiska Undersökning, Ser. Ca., 19, 1-94.

Wilmore, A. 1910. On the Carboniferous Limestone south of Craven Fault etc. Quarterly Journal of the Geological Society, 66, 539-585.

Yabe, H. \& Hayasaka, I. 1920. Atlas of fossils. Geographical research in China 1911-1916. Palaeontology of southern China, 1-221. Tokyo.

Yoh, S.S. 1927. On a new genus of syringoporoid coral from the Carboniferous of Chihli and Fengtien Provinces. Bulletin of the Geological Society of China, 5 (3-4), 291-294. 
